ZRC SAZU, UMETNOSTNOZGODOVINSKI INŠTITUT FRANCETA STELETA

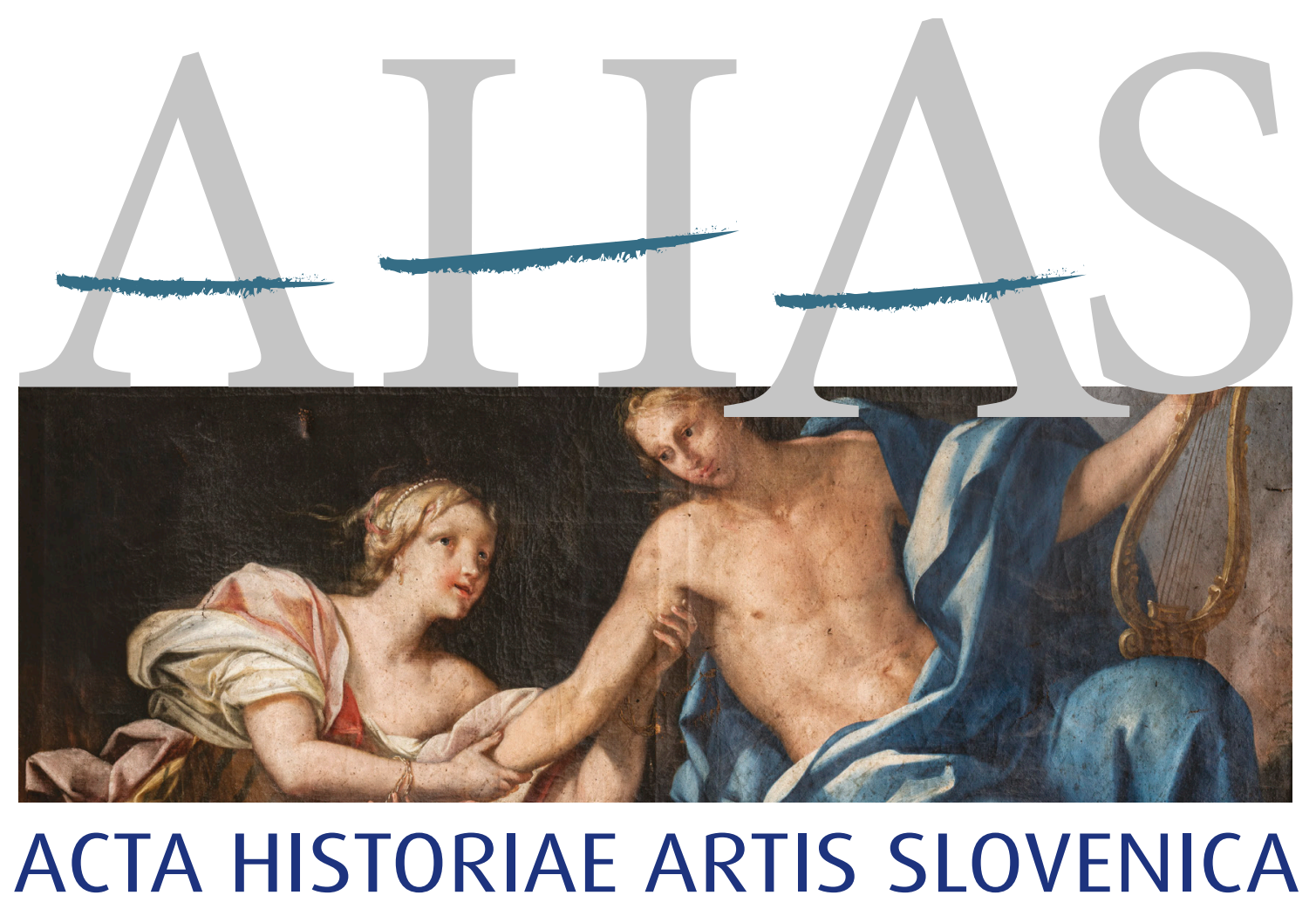

Frančišek Karel Remb in slikarstvo

v habsburških dednih deželah okrog leta 1700

Franz Carl Remp and Painting in the Habsburg Hereditary Lands around 1700

Franz Carl Remp und die Malerei in den habsburgischen Erblanden um 1700

$$
26 \mid 2 \cdot 2021
$$




\section{ACTA HISTORIAE ARTIS SLOVENICA $26 \mid 2 \cdot 2021$}

Frančišek Karel Remb in slikarstvo v habsburških dednih deželah okrog leta 1700

Franz Carl Remp and Painting in the Habsburg Hereditary Lands around 1700

Franz Carl Remp und die Malerei in den habsburgischen Erblanden um 1700 
Acta historiae artis Slovenica, 26/2, 2021

Frančišek Karel Remb in slikarstvo v habsburških dednih deželah okrog leta 1700

Franz Carl Remp and Painting in the Habsburg Hereditary Lands around 1700

Franz Carl Remp und die Malerei in den habsburgischen Erblanden um 1700

Znanstvena revija za umetnostno zgodovino / Scholarly Journal for Art History

ISSN 1408-0419 (tiskana izdaja / print edition) ISSN 2536-4200 (spletna izdaja / web edition)

ISBN 978-961-05-0568-6

Izdajatelj / Issued by

ZRC SAZU, Umetnostnozgodovinski inštitut Franceta Steleta /

ZRC SAZU, France Stele Institute of Art History

Založnik / Publisher

Založba ZRC

Urednika / Edited by

Edgar Lein, Polona Vidmar

Uredniški odbor / Editorial board

Renata Komić Marn, Tina Košak, Katarina Mohar, Mija Oter Gorenčič, Blaž Resman, Helena Seražin

Mednarodni svetovalni odbor / International advisory board

Günter Brucher (Salzburg), Ana María Fernández García (Oviedo), Hellmut Lorenz (Wien),

Milan Pelc (Zagreb), Sergio Tavano (Gorizia-Trieste), Barbara Wisch (New York)

Lektoriranje / Language editing

Oliver Currie, Manuela Dajnko, Andrea Leskovec

Prevodi / Translations

Alan Harvey Cook, Blaž Resman, Nika Vaupotič, Polona Vidmar

Celostni strokovni in jezikovni pregled / Expert and language editing

Blaž Resman

Oblikovna zasnova in prelom / Design and layout

Andrej Furlan

Naslov uredništva / Editorial office address

Acta historiae artis Slovenica

Novi trg 2, p. p. 306, SI -1001 Ljubljana, Slovenija

ahas@zrc-sazu.si; https://ojs.zrc-sazu.si/ahas

Revija je indeksirana v / Journal is indexed in

Scopus, ERIH PLUS, EBSCO Publishing, IBZ, BHA

Letna naročnina / Annual subscription: $35 €$

Posamezna enojna številka / Single issue: $25 €$

Letna naročnina za študente in dijake: $25 €$

Letna naročnina za tujino in ustanove / Annual subscription outside Slovenia, institutions: $48 €$

Naročila sprejema / For orders contact

Založba ZRC

Novi trg 2, p. p. 306, SI-1001, Slovenija

E-pošta / E-mail: zalozba@zrc-sazu.si

AHAS izhaja s podporo Javne agencije za raziskovalno dejavnost Republike Slovenije.

AHAS is published with the support of the Slovenian Research Agency.

(c) 2021, ZRC SAZU, Umetnostnozgodovinski inštitut Franceta Steleta, Založba ZRC, Ljubljana Tisk / Printed by Collegium Graphicum d.o.o., Ljubljana

Naklada / Print run: 400 


\section{VSEBINA \\ Contents}

Edgar Lein, Polona Vidmar

Frančišek Karel Remb in slikarstvo v habsburških dednih deželah okrog leta 1700. Predgovor ...........................5

Franz Carl Remp and Painting in the Habsburg Hereditary Lands around 1700. Preface .....................................7

Franz Carl Remp und die Malerei in den habsburgischen Erblanden um 1700. Vorwort .....................................9

\section{DISSERTATIONES}

Karin Požin

Remp's Ceiling Paintings in the Palais Attems in Graz. From Reproductive Prints to Frescoes

Rembove stropne poslikave v graški palači Attems. Od grafičnih predlog do fresk ...13

Georg Lechner

Franz Carl Remp zwischen Graz und Wien 31

Frančišek Karel Remb med Gradcem in Dunajem 48

Edgar Lein

Preis und Wert der Malerei um 1700. Zu den Kosten von Gemälden in der Steiermark 51

Cena in vrednost slik okrog leta 1700. O stroških za slike na Štajerskem

Renata Komić Marn

Zaplemba - prenos - distribucija. Slike grofa Attemsa iz gradu Slovenska Bistrica $v$ slovenskih javnih zbirkah

Confiscation - Transfer - Distribution. Count Attems' Paintings from

Slovenska Bistrica Castle in Slovenian Public Collections

Polona Vidmar

Emblematische Gratulationsschriften, Stammbäume und Porträts

von Dominik Franz Calin von Marienberg für das Haus Habsburg.

Emblematična voščila, rodovniki in portreti Dominika Frančiška Kalina

von Marienberga za Habsburžane

Ulrich Becker

Weltgeschichte im Wimmelbild. Stephan Kessler und der Entsatz von Wien 1683.

Svetovna zgodovina na »mrgoleči sliki«. Stephan Kessler in Rešitev Dunaja leta 1683 
Andreas Gamerith

Zeit des Experiments. Die Galleria maior des Stiftes Zwettl als Beispiel

für seicenteske Wandmalerei in Niederösterreich.

Čas eksperimentiranja. Galleria maior v samostanu Zwettl

kot primer stenskega slikarstva 17. stoletja v Spodnji Avstriji

\section{Martin Mádl}

The Patterns of the Transformation in Central European Ceiling Painting

around 1700 and Franz Carl Remp in Brežice Castle.

Vzorci transformacije v srednjeevropskem stropnem slikarstvu okrog leta 1700

in Frančišek Karel Remb v brežiškem gradu 


\section{Predgovor}

\section{FranČIŠEK KAREL REMB IN SLIKARSTVO V HABSBURŠKIH DEDNIH DEŽELAH OKROG LETA 1700}

Kljub razmeroma številnim slikam je ostal opus v Radovljici rojenega ter v Gradcu in na Dunaju delujočega slikarja Frančiška Karla Remba (1675-1718) široki javnosti doslej večinoma neznan. Prva in zaenkrat edina razstava Rembovih del je bila od 26. oktobra 1973 do 19. maja 1974 na ogled v Spodnjem Belvederu na Dunaju ter junija 1974 v vogalni sobi Stare galerije muzeja Joanneum v graški Neutorgasse. Razstavni katalog z naslovom Der Barockmaler Franz Carl Remp 1674-1718 vsebuje sedem strani obsegajoč uvod v umetnikovo življenje in delo, kataložni del z dvajsetimi enotami, časovnico in seznam literature.

Georg Lechner se je s Frančiškom Karlom Rembom ukvarjal v okviru svoje leta 2010 na Dunaju obranjene doktorske disertacije. Ko je spomladi 2018 Lechner opozoril, da se jeseni bliža tristota obletnica Rembove smrti, vendar ni niti na Dunaju niti v Gradcu načrtovana kakšna razstava slikarjevih del, smo se odločili za organizacijo simpozija, ki je pod naslovom Slikarji in naročniki. Frančišek Karel Remb in slikarstvo na Štajerskem okrog 1700 potekal 23. novembra 2018 v Laterneng'wölb dvorca Eggenberg. Naslednji dan so si udeleženci pod vodstvom Georga Lechnerja ogledali palačo Attems in pod vodstvom Paula Schusterja reprezentativne prostore dvorca Eggenberg. Simpozij so podprli univerzi v Gradcu in Mariboru ter Znanstvenoraziskovalni center Slovenske akademije znanosti in umetnosti, Umetnostnozgodovinski inštitut Franceta Steleta. Bil je del bilateralnega projekta BI SLO-AT/16-17-18: Umetnostni naročniki kot nosilci deželne identitete. Vloga in pomen naročnikov za gradnjo in opremo plemiških rezidenc in romarskih središč na Štajerskem, ki sta ga financirala Javna agencija za raziskovalno dejavnost Republike Slovenije in Österreichischer Austauschdienst, ter temeljnega raziskovalnega projekta J6-7410: Umetnostna reprezentacija plemstva. Naročništvo na Štajerskem $v$ zgodnjem novem veku (2016-2018), ki ga je financirala Javna agencija za raziskovalno dejavnost Republike Slovenije.

Simpozij so otvorili Georg Lechner s temeljnim prispevkom o Frančišku Karlu Rembu med Gradcem in Dunajem (Franz Carl Remp zwischen Graz und Wien), Christine Rabensteiner, ki je predstavila dela priseljenih in na Štajerskem rojenih baročnih slikarjev v depojih graške Stare galerije (Werke immigrierter und gebürtiger steirischer Barockmaler. Ein Blick in das Depot der Alten Galerie), ter Karin Požin s študijo o Rembovih stropnih poslikavah v palači Attems v Gradcu in likovnih virih zanje (Case Study of Remp's Ceiling Paintings in Palais Attems in Graz. From Reproductive Prints to Frescoes). V drugem delu je Edgar Lein predstavil ceno in vrednost slikarskih del okrog 1700 (Preis und Wert der Malerei um 1700), Tina Košak pa je na podlagi virov v mestnem arhivu v Antwerpnu raziskala trgovce $\mathrm{z}$ umetninami iz družine Forchondt in njihove štajerske stranke (The Forchondt Art Dealers and their Styrian Clients. Excerpts from the Antwerp City Archives). Renata Komić Marn je analizirala portrete Eleonore Marije Rozalije kneginje Eggenberg (The Portraits of Eleonora Maria Rosalia Princess of Eggenberg), Polona Vidmar pa je predstavila slikane genealogije štajerskega plemstva okrog leta 1700 (Gemalte Genealogien des steirischen Adels um 1700). Meje historične Štajerske so s svojimi referati presegli Ulrich Becker, ki je Stephanu Kesslerju pripisal upodobitvi Rešitve 
Dunaja leta 1683 (Weltgeschichte als Wimmelbild. Stephan Kessler und der Entsatz von Wien 1683), Andreas Gamerith, ki se je ukvarjal s stropnimi poslikavami pred Trogerjem oziroma okrog leta $1700 \mathrm{v}$ samostanih Zwettl in Altenburg (Vor Troger. Aspekte der Wandmalerei um 1700 am Beispiel der Klöster Zwettl und Altenburg), ter Martin Mádl z izčrpnim predavanjem o češkem stropnem slikarstvu okoli 1700 („So ist nun ... der Pracht im Bauen so hoch gestiegen ..... Profane Ceiling Painting in Bohemia around 1700).

Udeleženci simpozija so svoje referate pripravili za tisk ali pa so prispevali nova raziskovalna spoznanja, ki jih v Acta historiae artis Slovenica objavljamo pod naslovom Frančišek Karel Remb in slikarstvo v habsburških dednih deželah okrog leta 1700. Prispevka Karin Požin in Georga Lechnerja poglabljata vedenje o Rembovih stenskih poslikavah v palači Attems in o delih, ki jih je ustvaril po selitvi na Dunaj. Nekatere Rembove oljne slike so obravnavane tudi v prispevkih Edgarja Leina, ki se je posvetil stroškom za slike na Štajerskem, ter Renate Komić Marn, ki je raziskala slike iz Attemsove zbirke v Slovenski Bistrici v slovenskih javnih zbirkah. Slikarstvo zadnjih desetletij 17. stoletja je tema prispevkov Polone Vidmar, ki se je posvetila delom Dominika Frančiška Kalina von Marienberga za Habsburžane, in Ulricha Beckerja, ki je upodobitvi Rešitve Dunaja atribuiral tirolskemu slikarju Stephanu Kesslerju. Andreas Gamerith je Gallerio maior v samostanu Zwettl predstavil kot eksperiment v stropnem slikarstvu poznega 17. stoletja v Spodnji Avstriji, zvezek pa zaključuje prispevek Martina Mádla, ki se je posvetil transformaciji srednjeevropskega slikarstva okrog leta 1700 in pomembnim zgledom zanjo.

Upava, da bodo raznoliki prispevki in številne upodobitve spodbudili nadaljnje raziskovanje baročnega slikarstva. 


\section{Preface}

\section{Franz Carl Remp and Painting in THE HABSbURg Hereditary LANDS AROUND 1700}

The oeuvre of Radovljica born painter Franz Carl Remp (1675-1718) who worked in Graz and Vienna is little-known to the wider public despite his relatively numerous paintings. The first and only exhibition of Remp's works up to now was held from 26 October 1973 to 19 May 1974 at the Lower Belvedere in Vienna, and in the corner room of the present-day Universalmuseum Joanneum's Alte Galerie in Neutorgasse in Graz in June 1974. The exhibition catalogue entitled Der Barockmaler Franz Carl Remp 1674-1718 includes a seven-page introduction to the artist's life and work, a catalogue comprising twenty units, a chronology, and list of sources.

Georg Lechner researched Franz Carl Remp in his PhD thesis, which he defended 2010 in Vienna. In the spring of 2018, Lechner drew attention to the fact that the $300^{\text {th }}$ anniversary of the painter's death would occur in the autumn of the same year, and that neither Vienna nor Graz planned to commemorate the anniversary with an exhibition of the Baroque painter's works. We therefore decided to organize a conference entitled Painters and Patrons. Franz Carl Remp and Painting in Styria around 1700 that was held on 23 November 2018 at the Laterneng'wölb in the Eggenberg Castle. The following day the participants went on a tour of the Palais Attems, guided by Georg Lechner, as well as a tour of Eggenberg Castle's monumental rooms guided by Paul Schuster. The conference was supported by the Universities of Graz and Maribor, and the Research Centre of the Slovenian Academy of Sciences and Arts, the France Stele Institute of Art History. It formed part of the bilateral project BI SLO-AT/16-17-18: Art Patrons as Carriers of Province's Identity. The Role and Significance of Commissioners of Architectures and Furnishings of Aristocratic Residences and Pilgrimage Sites in Styria, which was financed by the Slovenian Research Agency and the Österreichischer Austauschdienst, and the research project J6-7410: Visual Representations of the Nobility. Early Modern Art Patronage in the Styria Province (2016-2018), financed by the Slovenian Research Agency.

The conference opened with Georg Lechner's general and foundational contribution - Franz Carl Remp between Graz and Vienna (Franz Carl Remp zwischen Graz und Wien) - followed by Christine Rabensteiner, who presented the works of immigrant and Styria-born Baroque painters in storage in the Alte Galerie in Graz (Werke immigrierter und gebürtiger steirischer Barockmaler. Ein Blick in das Depot der Alten Galerie), and Karin Požin with her study of Remp's ceiling paintings in Palais Attems in Graz and their sources (Case Study of Remp's Ceiling Paintings in Palais Attems in Graz. From Reproductive Prints to Frescoes). In the second part of the conference there were papers on the wider context and Styrian art of the period. Edgar Lein gave a spech on the cost and value of paintings around 1700 (Preis und Wert der Malerei um 1700). Tina Košak presented a study of the art dealers from the Forchondt family and their Styrian clients based on sources in the Antwerp city archives (The Forchondt Art Dealers and their Styrian Clients. Excerpts from the Antwerp City Archives). Renata Komić Marn analysed the portraits of Eleonora Maria Rosalia Princess of Eggenberg (The Portraits of Eleonora Maria Rosalia Princess of Eggenberg), and Polona Vidmar presented the painted genealogies of Styrian nobility around 1700 (Gemalte Genealogien des steirischen Adels um 
1700). The final section of the conference went beyond the borders of historical Styria: Ulrich Becker attributed the depictions of the Liberation of Vienna in 1683 to Stephan Kessler (Weltgeschichte als Wimmelbild. Stephan Kessler und der Entsatz von Wien 1683); Andreas Gamerith dealt with ceiling paintings in the Zwettl and Altenburg monasteries before Troger (Vor Troger. Aspekte der Wandmalerei um 1700 am Beispiel der Klöster Zwettl und Altenburg), and Martin Mádl gave a detailed paper on Czech ceiling painting around 1700 („So ist nun ... der Pracht im Bauen so hoch gestiegen .... Profane Ceiling Painting in Bohemia around 1700).

The conference participants prepared their papers for publication, or contributed new research findings, which are now being published in the Acta historiae artis Slovenica under the title Franz Carl Remp and Painting in the Habsburg Hereditary Lands around 1700. The contributions by Karin Požin and Georg Lechner deepen our knowledge of Remp's ceiling paintings in the Palais Attems, as well of the works he created after moving to Vienna. Some of Remp's oil paintings are also treated in the papers by Edgar Lein, who focuses on the cost of paintings in Styria, and by Renata Komić Marn, who discusses the paintings from the Attems collection in Slovenska Bistrica in Slovenian public collections. The topic of the papers by Polona Vidmar, who focuses on Dominik Franz Kalin von Marienberg's works for the Habsburg family, and Ulrich Becker, who attributes the depictions of the Liberation of Vienna to Tyrolian painter Stephan Kessler, is the painting of the last decades of the $17^{\text {th }}$ century. Andreas Gamerith discusses the Galleria maior in the Zwettl monastery as an experiment in ceiling painting in late $17^{\text {th }}$ century Lower Austria. The volume is concluded by Martin Mádl's contribution, which focuses on the transformation of Central European painting around 1700 and the models that were important for this transformation.

We hope that the diverse contributions and the numerous depictions will encourage further research in Baroque painting. 


\section{VORWORT}

\section{Franz CARl Remp UNd die MAlerei IN DEN HABSBURGISCHEN ERBLANDEN \\ UM 1700}

Trotz einer relativ großen Anzahl von Gemälden ist das CEuvre des in Radovljica in Slowenien geborenen und in Graz sowie Wien tätigen Malers Franz Carl Remp (1675-1718) einer breiten Öffentlichkeit bislang weitgehend unbekannt geblieben. Die erste und bislang einzige Ausstellung mit Werken des Malers wurde vom 26. Oktober 1973 bis zum 19. Mai 1974 im Unteren Belvedere in Wien und im Juni 1974 im Ecksaal der Alten Galerie des Joanneums in der Grazer Neutorgasse gezeigt. Das Katalogbändchen mit dem Titel Der Barockmaler Franz Carl Remp 1674-1718 enthält eine sieben Seiten umfassende Einführung zu Leben und Werk des Künstlers, einen Katalogteil mit zwanzig Einträgen, eine Zeittafel und ein Literaturverzeichnis.

Georg Lechner hat sich im Rahmen seiner 2010 in Wien abgeschlossenen Dissertation umfassend mit Franz Carl Remp befasst. Als Lechner im Frühjahr 2018 darauf hinwies, dass sich der 300. Todestag des Malers im Herbst nähere, aber weder in Wien noch in Graz eine Ausstellung mit Werken des Barockmalers geplant sei, beschlossen die Herausgeber, eine Tagung zu organisieren, die am 23. November 2018 unter dem Titel Maler und Auftraggeber. Franz Carl Remp und die Malerei in der Steiermark um 1700 im Laterneng'wölb von Schloss Eggenberg abgehalten wurde. Ergänzend dazu gab es am darauffolgenden Tag eine Besichtigung des Palais Attems unter der Leitung von Georg Lechner sowie eine Führung von Paul Schuster durch die Prunkräume von Schloss Eggenberg. Die von den Universitäten in Graz und Maribor sowie dem France Stele Institut für Kunstgeschichte am Forschungszentrum der Slowenischen Akademie der Wissenschaften und Künste unterstützte Veranstaltung war Teil des von der Slowenischen Forschungsagentur und dem Österreichischen Austauschdienst finanzierten bilateralen Projekts BI SLO-AT/16-17-18: Art Patrons as Carriers of Province's Identity. The Role and Significance of Commissioners of Architectures and Furnishings of Aristocratic Residences and Pilgrimage Sites in Styria sowie des von der Slowenischen Forschungsagentur finanzierten Forschungsprojekts J6-7410: Visual Representations of the Nobility. Early Modern Art Patronage in the Styria Province (2016-2018).

Den Anfang der Tagung machten Georg Lechner mit einem grundlegenden Vortrag über Franz Carl Remp zwischen Graz und Wien und Christine Rabensteiner mit Werke immigrierter und gebürtiger steirischer Barockmaler. Ein Blick in das Depot der Alten Galerie sowie Karin Požin mit einer Case Study of Remp's Ceiling Paintings in Palais Attems in Graz. From Reproductive Prints to Frescoes. Im zweiten Teil untersuchten Edgar Lein Preis und Wert der Malerei um 1700 und Tina Košak The Forchondt Art Dealers and their Styrian Clients. Excerpts from the Antwerp City Archives. Renata Komić Marn analysierte The Portraits of Eleonora Maria Rosalia Princess of Eggenberg und Polona Vidmar präsentierte Gemalte Genealogien des steirischen Adels um 1700. Den Blick über die Steiermark hinaus weiteten Ulrich Becker mit seinem Vortrag Weltgeschichte als Wimmelbild. Stephan Kessler und der Entsatz von Wien 1683, Andreas Gamerith mit einem Blick auf die Malerei Vor Troger. Aspekte der Wandmalerei um 1700 am Beispiel der Klöster Zwettl und Altenburg und Martin Mádl mit einem umfassenden Vortrag zum Thema „So ist nun ... der Pracht im Bauen so hoch gestiegen ..... Profane Ceiling Painting in Bohemia around 1700. 
Die Referenten und Referentinnen überarbeiteten ihre Vorträge für die Drucklegung oder präsentierten neue Forschungsergebnisse, die wir in den Acta historiae artis Slovenica unter dem Titel Franz Carl Remp und die Malerei in den habsburgischen Erblanden um 1700 veröffentlichen. Die Beiträge von Karin Požin und Georg Lechner erweitern das Wissen über Remps Wandmalereien im Palais Attems und über sein nach der Übersiedlung nach Wien geschaffenes Werk. Einige Ölgemälde Remps werden auch in den Beiträgen von Edgar Lein, der sich den Kosten für Gemälde in der Steiermark widmet, und Renata Komić Marn, die die Gemälde der ursprünglich in Schloss Slovenska Bistrica befindlichen Sammlung Attems in slowenischen öffentlichen Sammlungen untersucht, behandelt. Die Malerei in den letzten Jahrzehnten des 17. Jahrhunderts ist das Thema der Beiträge von Polona Vidmar, die die Werke Dominik Franz Calins von Marienberg für das Haus Habsburg präsentiert, und Ulrich Becker, der zwei Darstellungen des Entsatzes von Wien dem Tiroler Maler Stephan Kessler zuschreibt. Andreas Gamerith thematisiert die Galleria maior in Stift Zwettl als ein Experiment der Deckenmalerei des späten 17. Jahrhunderts in Niederösterreich. Der Band endet mit dem Beitrag von Martin Mádl, der sich der Transformation der mitteleuropäischen Wandmalerei um 1700 und ihren bedeutenden Vorbildern widmet.

Wir hoffen, dass die vielfältigen Beiträge und die zahlreichen Abbildungen zu einer weiteren Beschäftigung mit der Barockmalerei anregen werden.

Edgar Lein, Polona Vidmar 


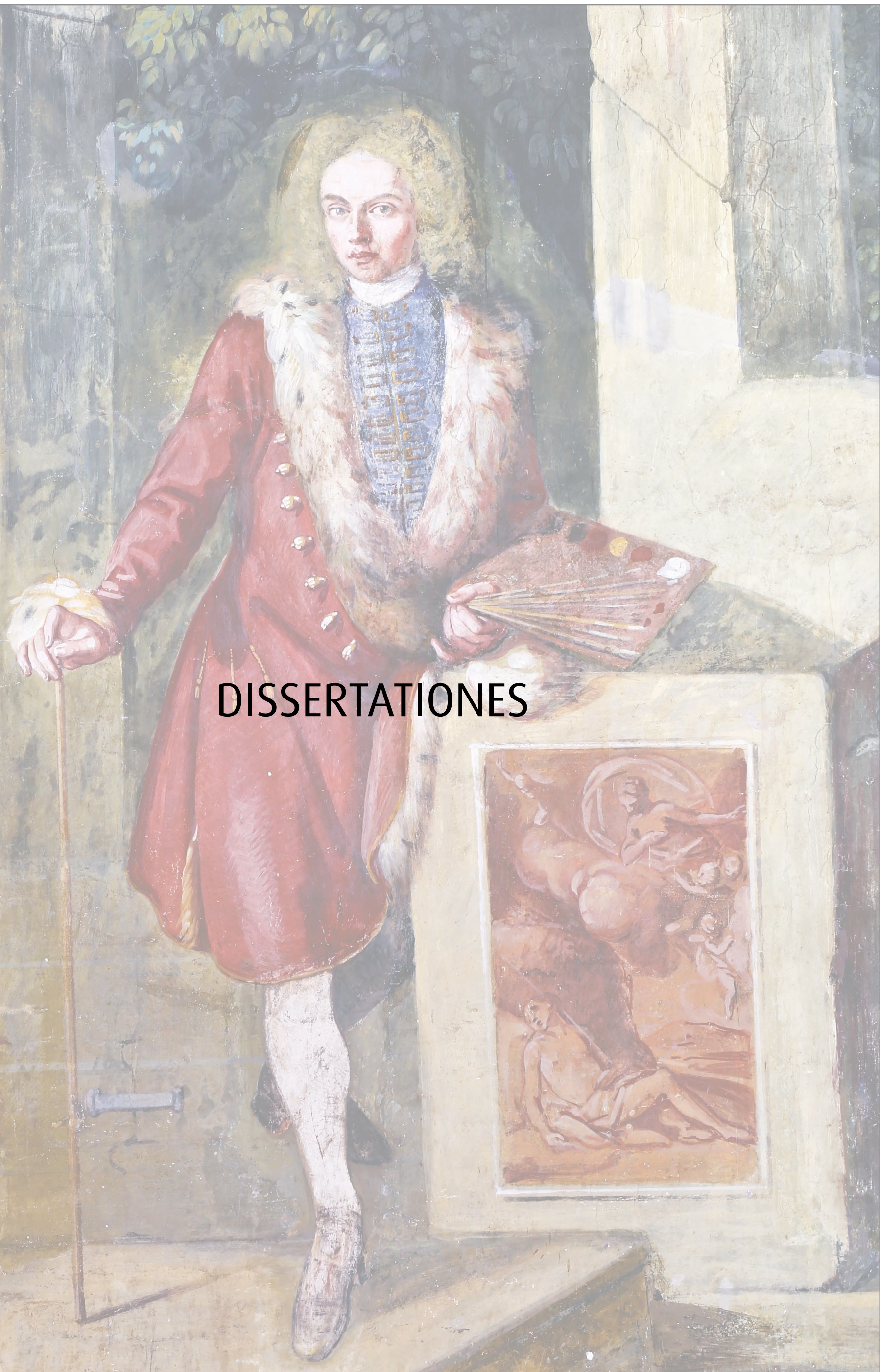





\title{
Remp's Ceiling Paintings in the Palais Attems in Graz
} From Reproductive Prints to Frescoes

\author{
Karin Požin \\ Karin Požin, Ulica Marjana Jerina 4, SI - 3000 Celje, \\ karin.pozin@gmail.com
}

Izvleček:

Rembove stropne poslikave v graški palači Attems. Od grafičnih predlog do fresk

1.01 Izvirni znanstveni članek

$\mathrm{V}$ 17. in 18. stoletju so bile grafične predloge med ključnimi posredniki likovnih rešitev in kot take pomemben del snovanja stropnih poslikav. V prispevku je obravnavan njihov vpliv na nastanek treh osrednjih fresk, ki jih je v graški palači Attems med letoma 1705 in 1711 naslikal Frančišek Karel Remb (1674-1718) za Ignaca Marijo grofa Attemsa (1652-1732). Vse tri obravnavane freske kažejo Rembovo uporabo grafičnih predlog, nastalih po delih italijanskih slikarjev Pietra da Cortone (1596-1669) in Annibala Carraccija (1560-1609). V nekaterih primerih je Remb upodobitve v celoti povzel po grafičnih predlogah, spet drugič pa so mu le-te služile zgolj kot kompozicijsko ali motivno izhodišče, ki ga je združil z drugimi viri in s tem ustvaril novo ikonografsko sporočilo.

Ključne besede: štajerski barok, stropne poslikave, freske, grafične predloge, Frančišek Karel Remb, Ignac Marija grof Attems, palača Attems v Gradcu

\begin{abstract}
:
Remp's Ceiling Paintings in the Palais Attems in Graz. From Reproductive Prints to Frescoes

1.01 Original scientific article

In the $17^{\text {th }}$ and $18^{\text {th }}$ century reproductive prints were one of the main mediators of artistic solutions and played a key role in the creation of ceiling paintings. This article discusses their use in three monumental frescoes in the Palais Attems in Graz, made by Franz Carl Remp (1674-1718) between 1705 and 1711, for Ignaz Maria Count Attems (1652-1732). All three frescoes testify of Remp's use of reproductive prints made after works by Italian painters Pietro da Cortona (1596-1669) and Annibale Carracci (1560-1609). In some cases, Remp's scenes are almost identical copies of depictions in reproductive prints, while sometimes they served as a compositional template or source for motifs, which he combined with other visual sources creating a whole new iconographic message.
\end{abstract}

Keywords: Styrian baroque, ceiling paintings, frescoes, reproductive prints, Franz Carl Remp, Ignaz Maria Count Attems, Palais Attems in Graz 
In the $17^{\text {th }}$ and $18^{\text {th }}$ century prints were one of the main mediators of artistic creations and as such an integral part of the decoration of aristocratic residences. Reproductive prints in particular reached a wide audience, enabling the dissemination of ideas, motifs, iconographical and compositional features, thus transposing their primary sources into an infinite array of visual references. ${ }^{1}$ The aim of this article is to discuss some newly identified reproductive prints in the context of three monumental frescoes in the Palais Attems in Graz made by Franz Carl Remp (1674-1718) ${ }^{2}$ for his patron Ignaz Maria Count Attems (1652-1732). ${ }^{3}$

The Palais Attems, a prestigious baroque palace in the north-western part of Graz, was commissioned by Ignaz Maria Count Attems, a patron of arts and founder of the Styrian branch of the Attems-Heiligenkreuz family. ${ }^{4}$ Plans and designs for the palace, which was built between 1702 and $1704,{ }^{5}$ were made by the Styrian architect Joachim Carlone (1653-1713), ${ }^{6}$ probably in close collaboration with the count himself, who was a passionate amateur architect. ${ }^{7}$ Most of the commissions for the ceiling paintings were granted to Remp, who came to Graz after he finished

1 For a more detailed definition of the reproductive print and its history, see Hans DICKEL, Deutsche Zeichenbücher des Barock. Eine Studie zur Geschichte der Künstlerausbildung, Hildesheim-Zürich-New York 1987 (Studien zur Kunstgeschichte, 48); David LANDAU, Peter PARSHALL, The Renaissance Print 1470-1550, New Haven 1994; Rebecca ZORACH, Elizabeth RODINI, On Imitation and Invention. An Introduction to the Reproductive Print, Paper Museums. The Reproductive Print in Europe, 1500-1800 (eds. Rebecca Zorach, Elizabeth Rodini), Chicago 2005, pp. 1-31.

2 For Remp's life and work, see Georg Matthias LECHNER, Der Barockmaler Franz Carl Remp (1675-1718), Wien 2010 (doctoral dissertation).

3 For Attems' life, acquisition of properties and art commissions, see Igor WEIGL, "Die Einheimischen bewundern die Gemälde". Graf Ignaz Maria von Attems-Heligenkreuz als Auftraggeber und Sammler, Kunsthistoriker, 18/19, 2001/2002, pp. 50-55; Dejan ZADRAVEC, Postavitev in postavljavec materialnih in rodbinskih temeljev plemiške družine Attems na Štajerskem, Zbornik občine Slovenska Bistrica. 3: Svet med Pohorjem in Bočem (ed. Stanislav Gradišnik), Slovenska Bistrica 2009, pp. 99-114; Barbara MUROVEC, Historizirana podoba naročnika. Attemsova družinska portreta in Rembov avtoportret iz brežiškega gradu, Acta historiae artis Slovenica, 23/1, 2018, pp. 113-131.

4 Günter BRUCHER, Die barocke Deckenmalerei in der Steiermark. Versuch einer Entwicklungsgeschichte, Graz 1973, p. 49; Wiltraud RESCH, Grazer Barockpalais - Ihre Stellung im überregionalen Kontext, Barock. Regional international (ed. Götz Pochat, Brigitte Wagner), Graz 1993 (= Kunsthistorisches Jahrbuch Graz, 25), pp. 311-312; Die Kunstdenkmäler der Stadt Graz. Die Profanbauten des I. Bezirkes. Altstadt (ed. Wiltraud Resch), Wien 1997 (Österreichische Kunsttopographie, 53), pp. 499-501; Karl MÖSENEDER, Franz Karl Remp (1674-1718), Merkur und Abundantia sichern den Reichtum des Hauses Attems, Barock (ed. Hellmut Lorenz), München-LondonNew York 1999 (Geschichte der bildenden Kunst in Österreich, 4), p. 336, cat. 89; Sigrid MOSETTIG, Das Stadtpalais der Grafen Attems zu Graz, Sackstrasse 17. Zur Bau- und Ausstattungsgeschichte, Graz 2007 (master thesis); Mark HENGERER, Embodiments of Power? Baroque Architecture in the Former Habsburg Residences of Graz and Innsbruck, Embodiments of Power. Building Baroque Cities in Europe (ed. Gary Cohen), New York 2008, p. 21; LECHNER 2010 (n. 2), pp. 47-49.

5 The beginnings of the planning for the monumental city palace date back to the year 1685, when Attems and his first wife Maria Regina Countess of Wurmbrand-Stuppach (1659-1715) married in Graz. It took a total of 15 years - from 1687 to 1702 - until Attems gradually acquired a land that was large enough to implement his project. First phase of construction of four-storied palace, together with ceiling frescoes, started in 1702 and was finished before 1715, when Countess of Wurmbrand-Stuppach died. For the architectural history of the palace and its influences, see MOSETTIG 2007 (n. 4), pp. 37-93.

6 For Carlone's life and work, see Rochus KOHLBACH, Steirische Baumeister. Tausendundein Werkmann, Graz 1961, pp. 187-188.

7 One of the first to note Attems' alleged architectural involvement in the construction of his city palace was RESCH 1993 (n. 4), pp. 311-312. Her notions were also confirmed by Igor WEIGL, Prenova gradu Podčetrtek v letih 17151723, Kronika. Časopis za slovensko krajevno zgodovino, 47/1-2, 1999, p. 32, and HENGERER 2008 (n. 4), p. 21. 
Attems' commission in Brežice Castle (between 1702 and 1703). ${ }^{8}$ Remp must have already started to work at the new location in Graz around 1705 and worked there until $1711 .{ }^{9}$

The comprehensive ceiling painting program in Palais Attems contains mythological, historical, personal and biblical depictions with allegorical allusions to the House of Attems. ${ }^{10}$ In his city palace, Attems continued the leading theme of his earlier residences: the glorification of the House of Attems and especially his patronage. ${ }^{11}$ The ideas for the visual representations of the glorification of the patron and his family were inspired by prominent European ceiling paintings, some of which were depicted in reproductive prints kept by both the commissioner and his painter in their collections. ${ }^{12}$ The influence of reproductive prints on ceiling paintings in Styria has been thoroughly researched by Günter Brucher, who showed that various motifs and compositional patterns were disseminated from major artistic centres to Styria through prints. ${ }^{13} \mathrm{He}$ was one of the first to suggest that Remp's frescoes in the second floor foyer in the Palais Attems were influenced by Pietro da Cortona's (1596-1669) ceiling paintings in the Palazzo Doria Pamphilj (1651-1654) in Rome. ${ }^{14}$ His findings were then summarized by all subsequent researchers discussing Remp's paintings in Palais Attems. ${ }^{15}$ The use of reproductive prints in Remp's oeuvre has also been highlighted by

8 MUROVEC 2018 (n. 3), p. 114.

9 Remp's work in Graz is proven in a statement by Count Attems in July 1707 to the municipal authorities that he had hired Remp "many years ago". Also, a recording of the baptism of Remp's daughter on 3 December 1707 can be found in the Graz central registry of births. After completing the ceiling decorations for the Palais Attems around 1711, Remp moved to Vienna. See LECHNER 2010 (n. 2), pp. 207-210.

10 BRUCHER, 1973 (n. 4), pp. 49-54; Die Kunstdenkmäler der Stadt Graz 1997 (n. 4), pp. 506-511; MÖSENEDER 1999 (n. 4), p. 336, cat. 89; MOSETTIG 2007 (n. 4), pp. 54-83; LECHNER 2010 (n. 2), pp. 47-54.

11 MUROVEC 2018 (n. 3), p. 121. Attems was inspired by the visual representation of key Italian and French artistic monuments (Hôtel Séguier, Villa Farnesina, Palazzo Rospigliosi Palaviccini), commissioners (Louis XIII and XIV of France, Pope Urban VIII, Farnese Family) and painters (Raphael (1483-1520), Guido Reni (1575-1642), Charles Le Brun (1619-1690), Simon Vouet (1590-1649), Nicolas Poussin (1594-1665)). These influences were important for both the painters, who collaborated with Attems, and the patron himself. Some of these influences have already been identified in Palais Attems, some will be unveiled in further research, as Attems (and his painters) were familiar with the many print series that shaped the aristocratic taste. See Barbara MUROVEC, Grafični listi po Simonu Vouetu in Charlesu Le Brunu kot predloge za baročne stropne poslikave na Kranjskem in Štajerskem, Acta historiae artis Slovenica, 1996, pp. 7-33; Barbara MUROVEC, Lepe umetnosti pod Attemsovim patronatom, Imago Musicae. Glasba na baročnih poslikavah brežiškega gradu (eds. Metoda Kokole, Barbara Murovec), Ljubljana 2016, pp. 13-14.

12 It was usual practice that painters presented their own collections of drawings and reproductive prints to the commissioner and tried to fulfil on the basis of these examples the patron's wishes. Remp held a collection of art books and reproductive prints, but unfortunately not much is known about it. When searching for influences, not only the artist's collections of visual sources must be taken into consideration, but also the patron's. Beside a large painting collection, archival sources show that Attems was in possession of David Teniers' Theatrum Pictorium (1660), in which he could study the painting collection of the Archduke Leopold Wilhelm of Austria. He also possessed books with reproductive prints made after Annibale Carracci's ceiling paintings in the Palazzo Farnese in Rome and those made after the paintings of Charles Le Brun, Louis XIV of France's court painter. See LECHNER 2010 (n. 2), pp. 83-84, 227-230; MUROVEC 2018 (n. 3), p. 119. For the Attems' painting collection in Palais Attems, see Katra MEKE, Slikarska zbirka Ignaca Marije grofa Attemsa, Zbornik za umetnostno zgodovino, n. s. 50, 2014, pp. 81-127.

13 BRUCHER 1973 (n. 4).

14 BRUCHER 1973 (n. 4), p. 52. For Cortona’s life and work, see Jörg Martin MERZ, Pietro da Cortona. Der Aufstieg zum führenden Maler im barocken Rom, Tübingen 1991 (Tübinger Studien zur Archäologie und Kunstgeschichte, 8).

15 Armgard SCHIFFER-EKHART, Das Stadtpalais der Grafen Attems zu Graz, Graz 1993, pp. 4-5; Edith ALTMANN, Der Pöllauer Stiftsmaler Matthias von Görz (1670-1731) und seine Zeitgenossen, Graz 1994 (doctoral dissertation), pp. 55-56; Die Kunstdenkmäler der Stadt Graz 1997 (n. 4), pp. 509-510; MÖSENEDER 1999 (n. 4), p. 336, cat. 89; MOSETTIG 2007 (n. 4), pp. 54-83; LECHNER 2010 (n. 2), pp. 47-54. 
Barbara Murovec in her studies, although she has not dealt specifically with the frescoes in the Palais Attems. ${ }^{16}$ She concludes that Remp's first commission for Attems - a ceiling painting for the Great Hall (1702-1703) in Brežice Castle ${ }^{17}$ - was greatly influenced by Cortona's ceiling painting Allegory of Divine Providence (1633-1639) in the Palazzo Barberini in Rome and that several figural compositions were copied from the series of prints in Charles Perrault's Le Cabinet des Beaux Arts (1690). ${ }^{18}$ Similarly, Georg Lechner in his doctoral dissertation Der Barockmaler Franz Carl Remp (1675-1718), devoted a chapter to cases of motif transfers, compositional role models and reproductive prints in Remp's oeuvre. ${ }^{19}$ Lechner stated that in some of Remp's (ceiling) paintings the use of reproductive prints seems to be obvious, while in others, the painter used elements very common for Italian paintings, which makes the identification of a specific reproductive print almost impossible. $^{20}$

So far, we do not know the precise archival sources which could give us an insight into the preparatory processes for decorating the palace, but we may assume that the ceiling frescoes Mercury and Abundance providing welfare to House of Attems, Elderly Ignaz Maria Count Attems receiving his longed-for medals and The Apotheosis of Young Ignaz Maria Count Attems - on the monumental staircase and in the foyers on both floors - were certainly made in close collaboration between the painter and the patron. ${ }^{21}$

The first of the three discussed frescos is Mercury and Abundance providing welfare to House of Attems. ${ }^{22}$ On the almost square ceiling of the monumental staircase Remp depicted illusionistic architecture opening upward into heavenly spheres, richly decorated with shells, floral vases, festoons and putti. ${ }^{23}$ In the center of the fresco is Mercury, floating on clouds towards the allegorical

16 Barbara Murovec focused mostly on visual sources in baroque ceiling paintings in the Slovene part of Styria. See MUROVEC 1996 (n. 11), pp. 28-29, 33; Barbara MUROVEC, Grafični cikli Ovidovih Metamorfoz in njihov vpliv na baročno slikarstvo na Slovenskem, Ljubljana 1998 (master thesis); Barbara MUROVEC, Evropski likovni viri za baročno stropno slikarstvo v Sloveniji, Ljubljana 2000 (doctoral dissertation); Barbara MUROVEC, Likovni viri za baročno stropno slikarstvo v Sloveniji, Zbornik za umetnostno zgodovino, n. s. 39, 2003, pp. 99-102.

17 For Remp's work in Brežice, see Jolanda Rebecca NUSSDORFER, Zur Baugeschichte und Ausstattung der Attems-Schlösser: Windisch-Feistritz (Slovenska Bistrica), Rann (Brežice), Stattenberg (Štatenberg) und Dornau (Dornava) in der ehemaligen Untersteiermark, Graz 1994 (master thesis), pp. 41-42; see also Marjana LIPOGLAVŠEK, Baročno stropno slikarstvo na Slovenskem, Ljubljana 1996, pp. 95-98; WEIGL 2001/2002 (n. 3), pp. 51-54; MUROVEC 2003 (n. 16), pp. 100-102 (with earlier literature); LECHNER 2010 (n. 2), pp. 27-53.

18 For the Perrault's series, see Marie-Pauline MARTIN, Le Cabinet des Beaux Arts de Charles Perrault. Le monument d'un Moderne, La Revue de l'art, 190/4, 2015, pp. 9-18.

19 LECHNER 2010 (n. 2), pp. 83-92.

20 LECHNER 2010 (n. 2), pp. 83-92.

${ }^{21}$ Attems didn't just commission ceiling paintings, but also closely supervised their creation, which can further explain the quite often usage of the same reproductive prints by various painters who worked for him. For example, the figure of Hercules found on the ceiling painting Love conquers War in the fourth room of the second floor of the Palais Attems, was probably influenced by Peter Paul Rubens' (1577-1640) Hercules from The Apotheosis of James I. (1630-1634), engraved by Flemish engraver Christoffel Jegher (1596-1653). The same figure is also part of ceiling painting The Allegory of the Five Senses (1718) in the monumental staircase of Attems Brežice Castle, painted by Johann Caspar Waginger (?-1718). For influence of Rubens' Hercules, see Maja ŽVORC, Herculean Allegory at the Čakovec Old Castle: Commissioner and Context, Radovi Instituta za povijest umjetnosti, 41, 2017, p. 83-96. For Waginger's work in Brežice, see Barbara MUROVEC, Wagingerjeva alegorija petih čutov v gradu Brežice, Vita artis perennis. Ob osemdesetletnici akademika Emilijana Cevca, Ljubljana 2000, pp. 403-408.

22 For iconographic interpretations, see BRUCHER 1973 (n. 4), p. 49; Die Kunstdenkmäler der Stadt Graz 1997 (n. 4), p. 507, MOSETTIG 2007 (n. 4), p. 65; LECHNER 2010 (n. 2), pp. 50, 58, 122-123.

23 BRUCHER 1973 (n. 4), p. 50 primarily pointed out influences of Genoese painter Domenico Piola (1627-1703) 
1. Pietro Aquila after Annibale Carracci: Intelligence and Chastity, in: Imagines Farnesiani cubiculi cum ipsarum monocromatibus et ornamentis, Romae, c. 1680

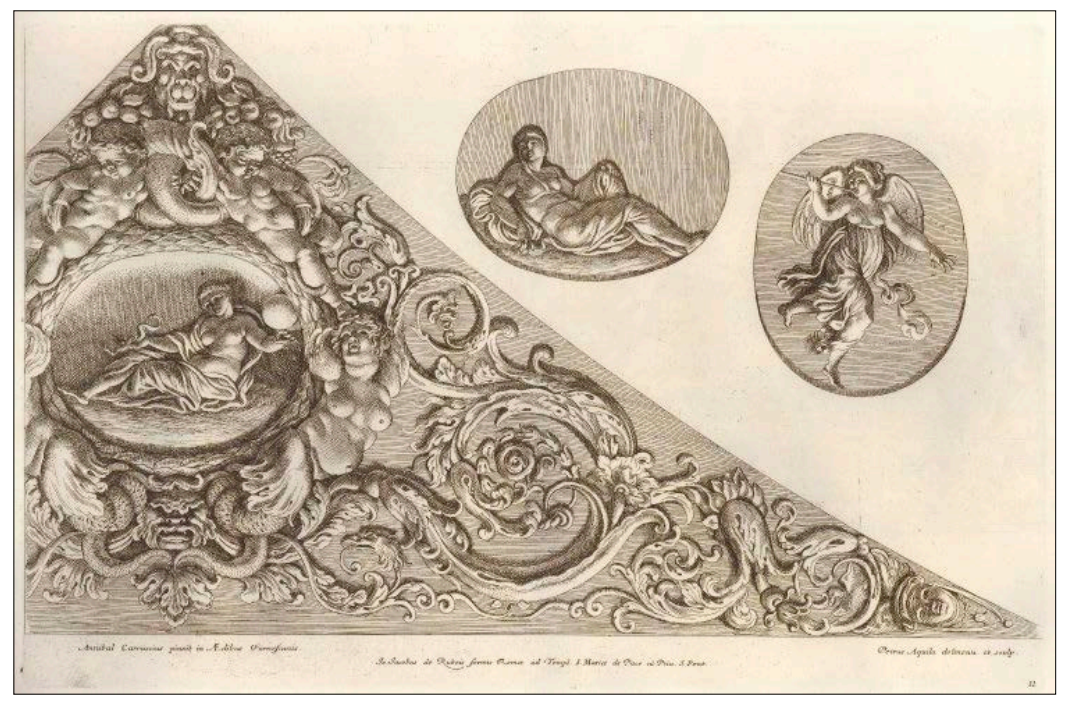

figure of Abundance. A cornucopia filled with laurel leaves, which is her attribute, is held by a putto floating above her, showing that Jupiter's wish of providing welfare to the Attems family is fulfilled. ${ }^{24}$ The patron's family is indicated by coats of arms on the edges of the architectural framework, and four ancient-style busts, probably depicting idealized portraits of members of the Attems family. ${ }^{25}$ On opposite sides of the architectural frame there are two smaller scenes with female figures, which have not yet been iconographically explained. We can identify that they have been modelled on Annibale Carracci's (1560-1609) works in the Camerino Farnese (1595-1597) ${ }^{26}$ as figures of Intelligence and Chastity, which were reproduced in the series Imagines Farnesiani cubiculi cum ipsarum monocromatibus et ornamentis (1670-1692; fig. 1$)^{27}$ made by the Italian engraver Pietro Aquila (1630-1692). ${ }^{28}$ Remp's depiction retains the original style and composition of the female body types, but putti and a stylized landscape are added, which were not in either

on Remp's illusionistic architectural frameworks, but we must add that in Remp's work in Palais Attems a major influence by Bolognese quadraturists is also evident. Lechner compared the illusionistic architectural framework with the ceiling paintings in Villa Albergati in Zola Predosa, painted by Angelo Michele Colonna and Giacomo Alboresi in 1665; see LECHNER 2010 (n. 2), p. 122.

24 BRUCHER 1973 (n. 4), pp. 50-51.

25 Ancient-style busts probably depict Count Attems, his first wife and their eldest surviving children Franz Dismas (1688-1750) and Charlotte Maria Anna Henriette (1687-1742). Lechner assumed, that they depict Roman emperors; see LECHNER 2010 (n. 2), p. 122.

26 For Carracci's ceiling paintings in Camerino Farnese, see John Rupert MARTIN, Immagini della virtù. The Paintings of the Camerino Farnese, The Art Bulletin, 38/2, 1956, pp. 91-112.

27 Imagines Farnesiani cubiculi cum ipsarum monocromatibus et ornamentis Romae in aedibus Sereniss. ducis parmensis. ab Annibale Carraccio aeternitati pictae. A Pietro Aquila delineatae incisae. Io. Jacobus de Rubeis cura, sumptibus, ac typis editae Romae ad Templ. S. Mariae de Pace cum Priv. S. Pont. (1670-1692). See Evelina BOREA, Ginevra MARIANI, Annibale Carracci e i suoi incisori, Roma 1986, pp. 73-80, where the texts are transcribed and the images are reproduced. After Carracci's frescoes, several series of reproductive prints were made, some of which Barbara Murovec has already connected with works in Attems' residences in Slovenia. See MUROVEC 2003 (n. 16), p. 100. The reproductive print from the series mentioned above is here for the first time associated with Remp's work in the Palais Attems.

28 For life and work of Pietro Aquila, see Alfredo PETRUCCI, Pietro Aquila, Dizionario biografico degli Italiani, 3 , Roma 1961, pp. 656-657. 




2. Franz Carl Remp: Diana, detail of the fresco in the monumental staircase, 1705-1711, Palais Attems, Graz

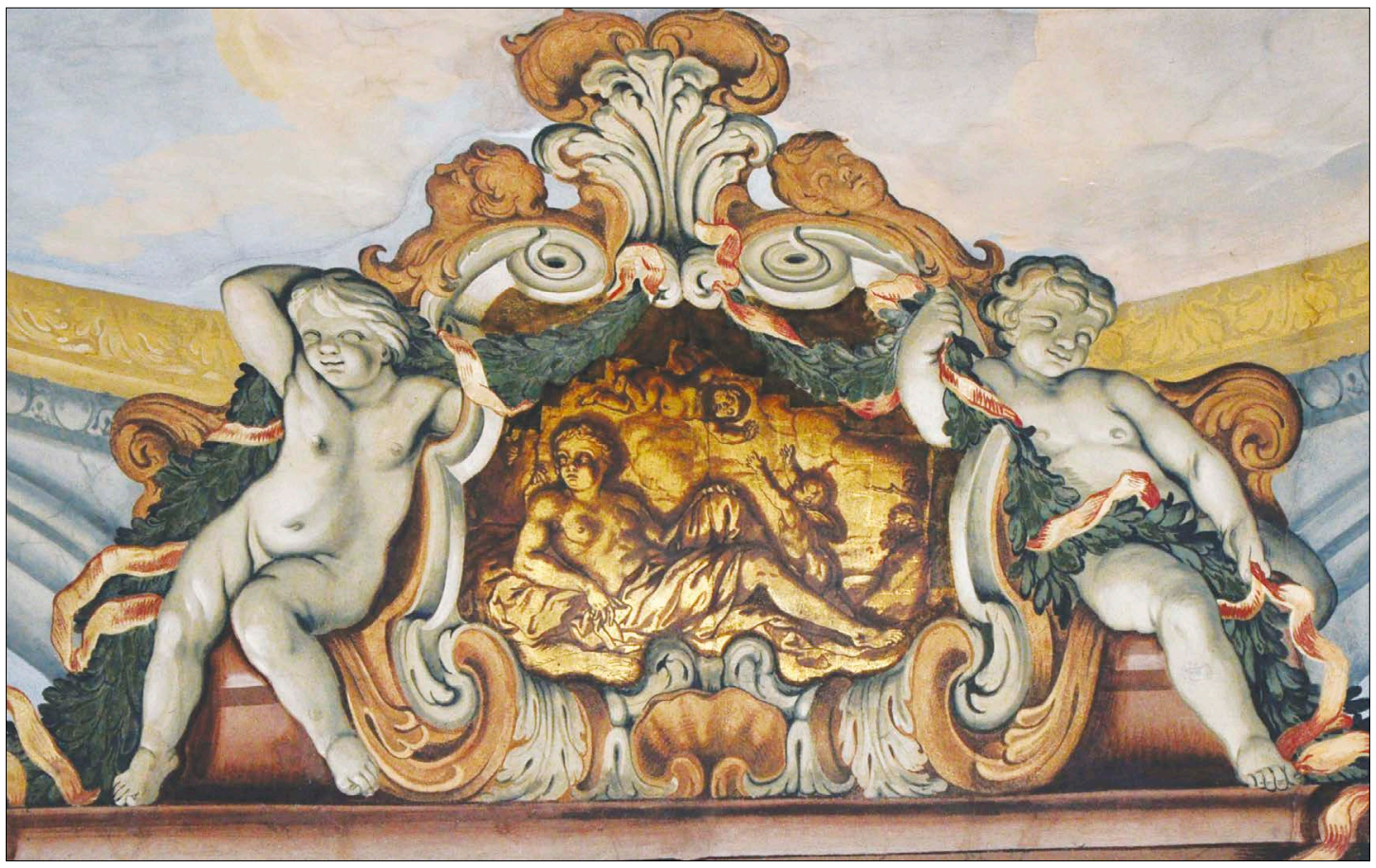

3. Franz Carl Remp: Venus, detail of the fresco in the monumental staircase, 1705-1711, Palais Attems, Graz 
Carracci's fresco or Aquila's print (figs. 2-3). He also made some adjustments to the iconography Intelligence was changed to the goddess Diana, holding a bow, and Chastity to the goddess Venus with playful putti, together personifying the duality of Purity and Desire.

The second fresco is on the first-floor foyer and depicts Elderly Ignaz Maria Count Attems receiving his longed-for medals. ${ }^{29}$ The aged Attems is kneeling and praising the god Jupiter, who, in the form of an eagle, is bestowing upon him as a sign of imperial grace the medals he has earned. ${ }^{30}$ The scene is followed by a female hovering between the two protagonists, holding her hand in a gesture of blessing over Attems' head, which is intended as a public demonstration of the confirmed divinity. A second female beholds floating putti playing with clouds and gestures the public away from the heavenly scene. ${ }^{31}$ The central scene is accompanied by allegories of the four seasons, symbolized by gods and putti performing typical seasonal tasks. The figural scene is surrounded by an illusionistic architectural framework dissolving into ornamental shapes, replete with Ignudi and Atlantes, probably influenced by Carracci's fresco The Loves of the Gods (1597-1608) in the Palazzo Farnese, ${ }^{32}$ which was reproduced in the series Galeriae Farnesianae Icones (1674) made by Aquila. ${ }^{33}$ Comparison shows that Remp preserved the original style and body types of the Ignudi and Atlantes as he did in the staircase, but adjusted their limbs and positions due to spatial constraints. An even more pronounced connection to reproductive prints can be seen in the four scenes accompanying the central scene and which allude to the moral virtues of the nobleman, but which have so far not been identified. Three out of four scenes can be directly connected to the ceiling paintings by Cortona in the Planetary Rooms (1641-1665) in the Palazzo Pitti in Florence, ${ }^{34}$ which were published by the Dutch engraver Cornelis Bloemaert (1603-1692) $)^{35}$ in the series Heroicae virtutis imagines (1691). ${ }^{36}$

The first scene, where the compositional, stylistic and iconographic meaning of the latter reproductive print is almost completely unchanged, depicts The Continence of Scipio (Livius 26, 50;

29 For iconographic interpretations, see BRUCHER 1973 (n. 4), p. 50; Die Kunstdenkmäler der Stadt Graz 1997 (n. 4), pp. 507-508; MOSETTIG 2007 (n. 4), p. 66; LECHNER 2010 (n. 2), p. 123.

30 Friedrich POLLEROSS, Auftraggeber und Funktionen barocker Kunst in Österreich, Barock 1999 (n. 4), pp. 37 38. Attems never received the medals which the eagle is bearing, although he craved them, a fact which is verified by biographical information.

31 MOSETTIG 2007 (n. 4), pp. 66-67.

32 For the Farnese Gallery, see Charles DEMPSEY, Annibale Carracci. The Farnese Gallery, Rome, New York 1995.

33 Galeriae Farnesianae Icones Romae in aedibus Sereniss. Ducis parmensis ab Annibale Carracio ad Veterum aemuationem posterorumq. admiratioe coloribus expressae cum ipsarum monocromatibus et ornamentis. A Petro Aquila delineatae incisae. Io: Iacobi de Rubeis cura, sumptibus ac typis excusae. Romae ad Templum S. Mariae de Pace cum Privil. Summi Pontificis, 1677. See MUROVEC 2003 (n. 16), p. 101.

34 For Cortona's works in Palazzo Pitti, see Malcolm CAMPBELL, Cortona at the Pitti Palace. A Study of the Planetary Rooms and Related Projects, New Jersey 1977.

35 For life and work of Bloemaert, see Laura BARTONI, Le vie degli artisti. Residenze e botteghe nella Roma barocca dai registri di Sant'Andrea delle Fratte (1650-1699), Roma 2012, p. 430.

36 Heroicae virtutis imagines, quas eques Petrus Berrettinus Cortonensis pinxit Florentiae in aedibus sereniss. Magni DucisHetruriae in tribus cameris, Jovis, Martis, et Veneris. Curâ, \& sumptibus Ioannis Iacobi de Rubeis, cum Priuilegio Summi Pontificis conccesso Anno MDCXCI. die 22. Octobris Romae, Apud Dominicum de Rubeis eiusdem Ioannis Iacobi Haeredem ad Templum S. Mariae de Pace /.../. Superiorum Permissu, Romae 1691. See Bettina BAUMGÄRTEL, Die Tugendheldin als Symbol kirchlicher und staatlicher Macht. Über die Galerie der starken Frauen in Ausstattungsprogrammen und Buchillustrationen, Die Galerie der Starken Frauen/La Galerie des Femmes Fortes. Regentinnen, Amazonen, Salondamen (eds. Bettina Baumgärtel, Silvia Neysters), München-Berlin 1995, p. 181 , where the images are reproduced. 

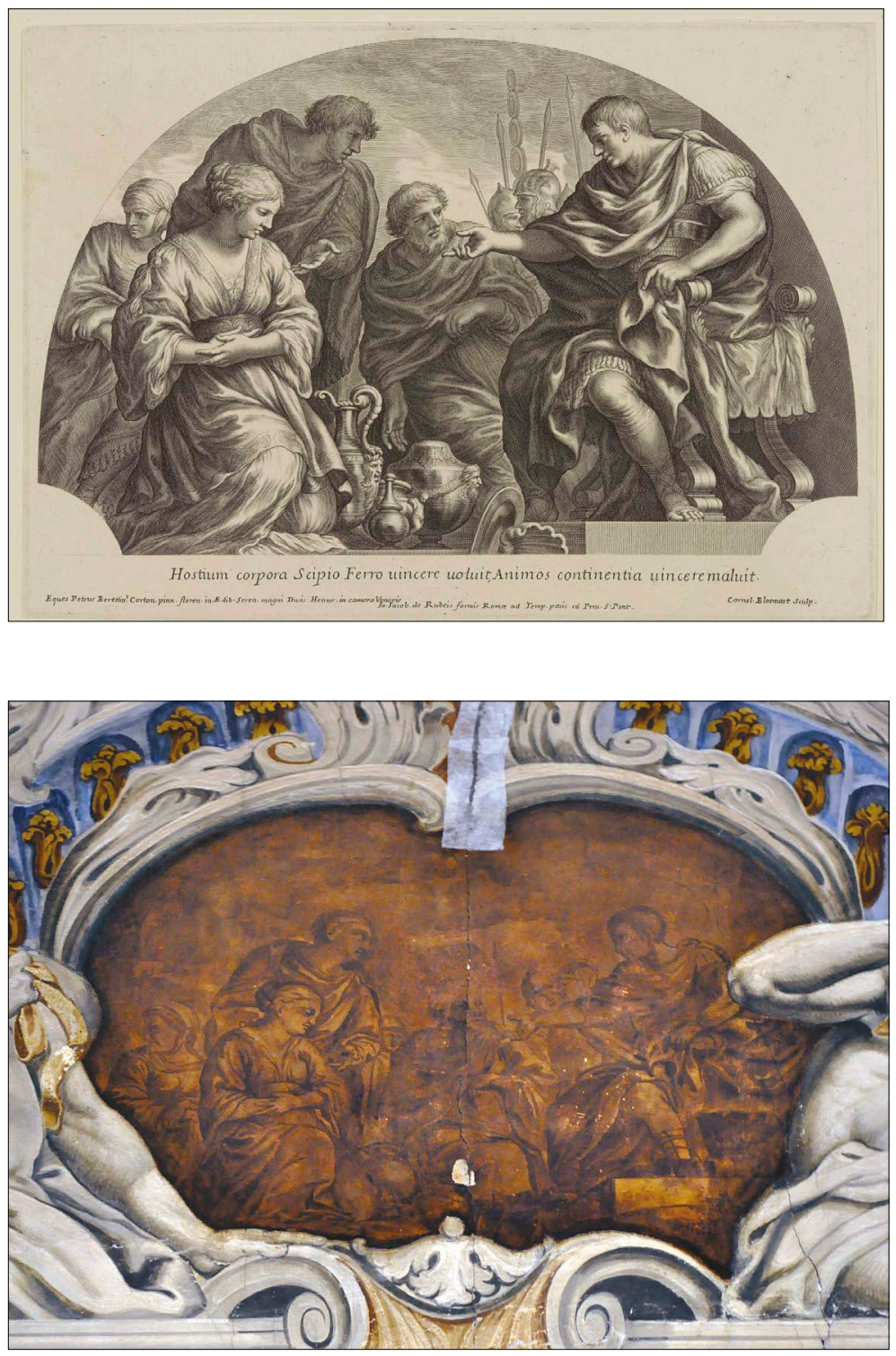

4. Cornelis Bloemaert after Pietro da Cortona: The Continence of Scipio, in: Heroicae virtutis imagines, Romae 1691

\section{Franz Carl Remp:}

The Continence of Scipio, detail of the fresco in the first-floor foyer, 1705-1711, Palais Attems, Graz

Petrarca 4, 375-388), which represents a noble act and one of the prime examples of clemency and mercy during warfare (fig. 4). Scipio Africanus, the Roman general, is granting a suppliant young woman permission to return to her fiancé rather than claiming her for himself. Remp preserved the original iconographic meaning as well as the figural composition with Scipio seated on a throne pointing towards the woman, who is kneeling on his left, with two men and a female attendant in the background (fig. 5).

The scene on the opposite side depicts Sisygambis kneeling before Alexander the Great (Plutarch 33, 21). Sisygambis, mother of Darius III of Persia, was captured by Alexander the Great at the Battle of Issus and became devoted to him (figs. 6-7). Confused by the values of freedom and equality in the conqueror's culture, the queen throws herself at emperor's feet, begging for clemency. Remp preserved the original composition but left out a number of soldiers in the background, while preserving the iconographic message of the scene, which emphasizes Alexander's human side. This scene is a parallel to The Continence of Scipio, since Alexander is depicted as a civilized monarch, who chooses mercy over plunder when dealing with his defeated enemies. 
6. Cornelis Bloemaert after Pietro da Cortona: Sisygambis kneeling before Alexander the Great, in: Heroicae virtutis imagines, Romae 1691

\section{Franz Carl Remp:} Sisygambis kneeling before Alexander the Great, detail of the fresco in the first floor-foyer, 1705-1711, Palais Attems, Graz
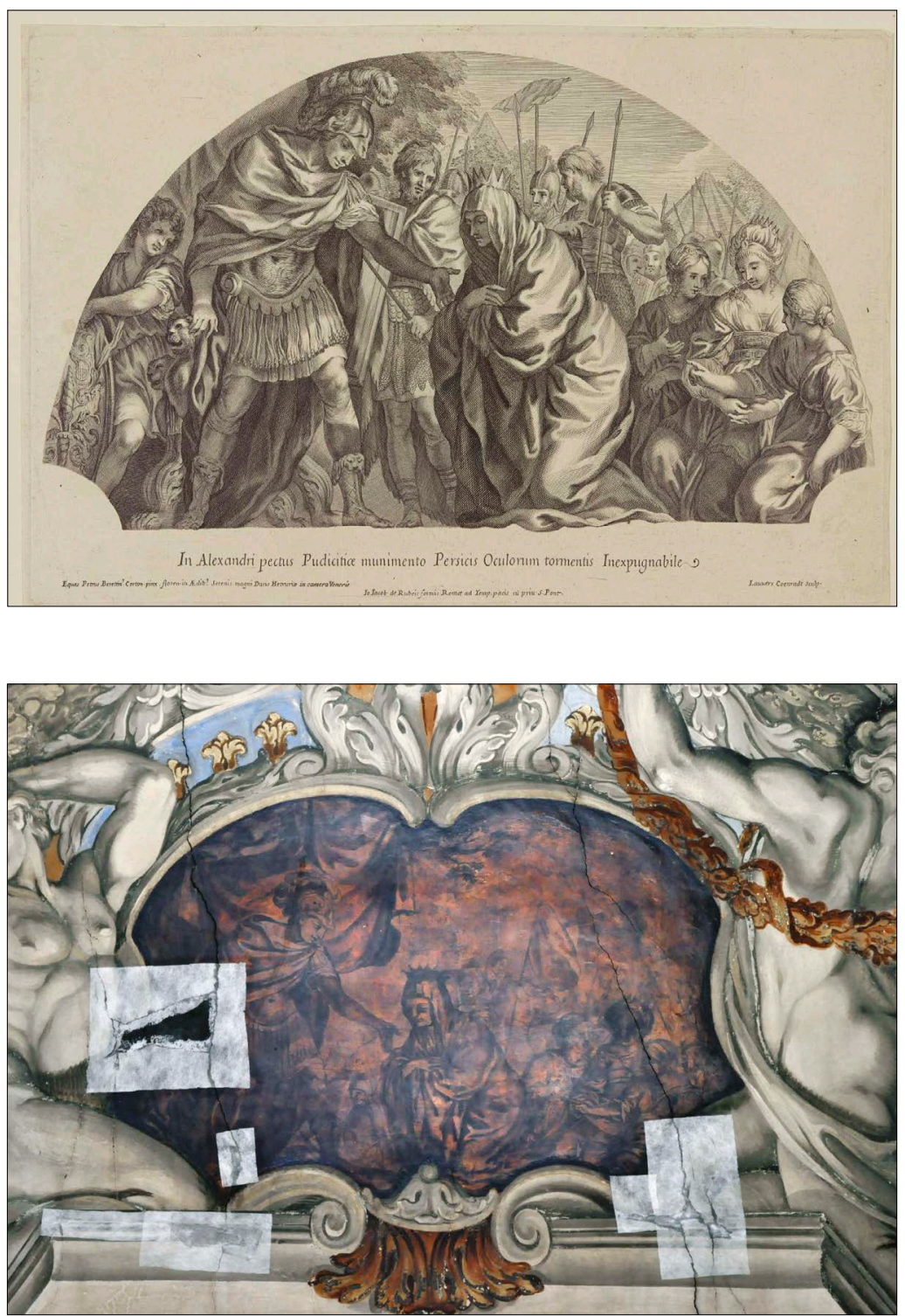

The third scene depicts the god Apollo as a young nude representing an ideal male beauty, sitting in a landscape. Both the compositional and iconographic motifs have again been copied from Bloemaert's reproductive print (figs. 8-9).

On the opposite side of the Apollo is a scene probably depicting the sleeping Venus and a Satyr. Since a direct visual source cannot be found in the series Heroicae Virtutis Imagines, we can compare the scene, because of the apparent similarities, to the reproductive print Venus and Satyr made after Agostino Carracci (1557-1602). ${ }^{37}$ The compositional similarity is evident especially in the figure of

37 It is possible that further research will find a matching reproductive print, especially because this was a popular scene. A further similarity can be seen with Hans Adam Weissenkircher's (1646-1695) painting Jupiter and Antiope (1695), influenced by Johann Carl Loth's (1632-1698) School in Venice, where Remp most likely spent some time. The composition of Venus and Satyr can also be found in a small medallion in Brežice Castle. See LECHNER 2010 (n. 2), p. 84. 


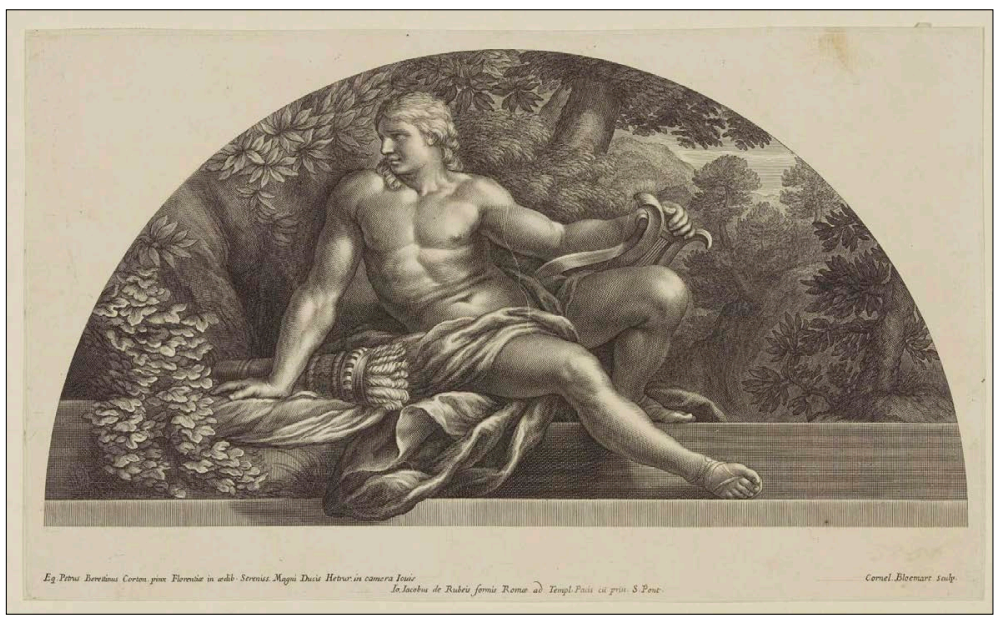

8. Cornelis Bloemaert after Pietro da Cortona: Apollo, in: Heroicae virtutis imagines, Romae 1691

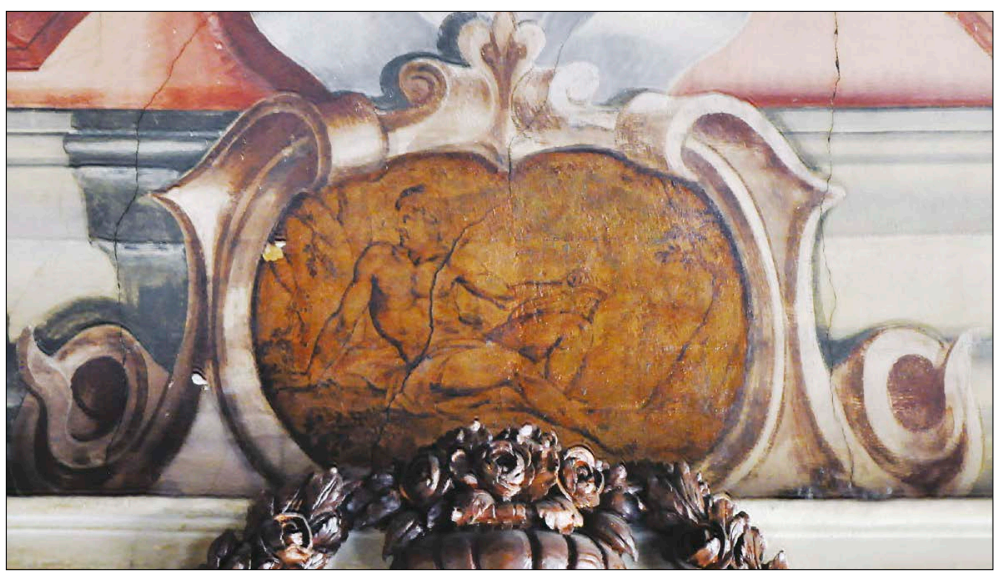

9. Franz Carl Remp: Apollo, detail of the fresco in the first floor-foyer, 1705-1711, Palais Attems, Graz

Venus, who lies in the same position, while the Satyr is compositionally designed much more freely. It is possible that this pair of scenes alludes to the duality of human nature: Apollo embodies a rational and civilized side, while Satyr represents unrestrained desire.

The last fresco discussed is located in the second floor foyer and depicts the Apotheosis of Young Ignaz Maria Count Attems. ${ }^{38}$ Its architectural framework has been attributed to Remp, while the central figural part has been attributed to the Styrian painter Matthias von Görz (1671-1731). ${ }^{39}$ Görz depicted the ascension of the young Attems, carried by Mercury towards the crown of glory at the same time as being held down by evil spirits, while Hercules attacks them and helps him ascend. A female nude held up by two servants possibly personifies his first wife, the Countess of Wurmbrand, in the role of Truthfulness, with the god Cronus below her, whose wings are being

38 For iconographic interpretations, see BRUCHER 1973 (n. 4), p. 52; Die Kunstdenkmäler der Stadt Graz 1997 (n. 4), p. 508; ALTMANN 1994 (n. 15), pp. 54-55; MOSETTIG 2007 (n. 4), p. 67; LECHNER 2010 (n. 2), p. 124.

39 Görz, who became member of Graz painters' guild in 1706, worked for the Count Attems at least three times; besides the Palais Attems, he painted ceiling decorations in St. Mary's pilgrim church in Zagorje near Pilštanj (1708-1709), and later the decoration of Attems' Neu-Gösting Manor (1724-1728). For the life and work of Matthias von Görz, see ALTMANN 1994 (n. 15), pp. 19-29. 


\section{Carlo Cesio}

after Pietro da Cortona:

Pair of Ignudi, in: Galeria dipinta nel palazzo del Prencipe Panfilio, Romae, 1661 or later
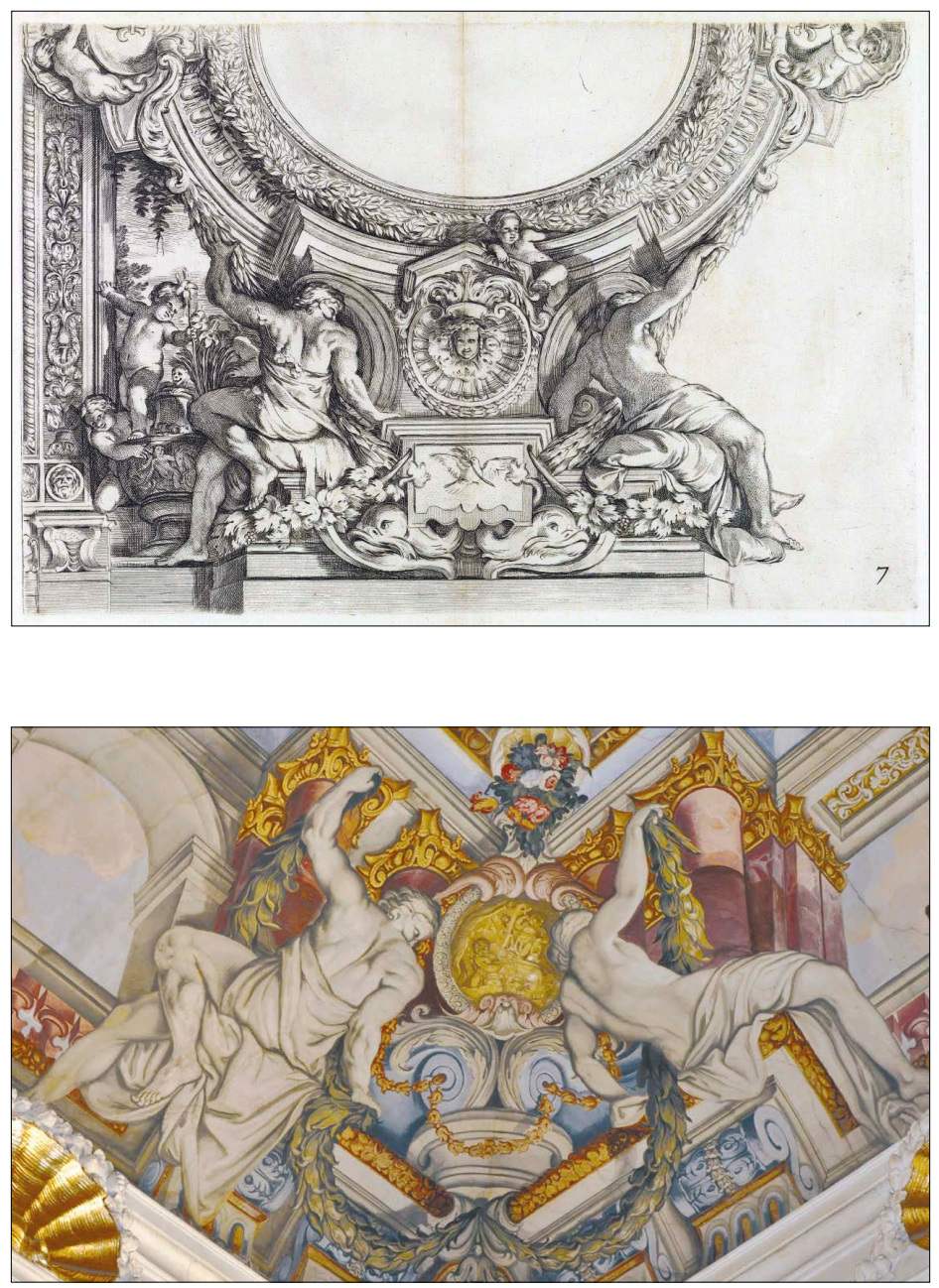

\section{Franz Carl Remp: Corner} composition (Element of Water), detail of the fresco in the second floor-foyer, 1705-1711, Palais Attems, Graz trimmed by a putto, symbolizing a claim to eternity. The creation of the figural part was greatly influenced by the ceiling painting Truth overcoming Time painted in 1697 by the Italian painter Antonio Bellucci (1654-1726) for the Palais Liechtenstein in Vienna ${ }^{40}$ Görz copied the majority of the figures from Bellucci's creation but rearranged them to fit the ceiling of the second-floor foyer in Palais Attems. ${ }^{41}$

40 BRUCHER 1973 (n. 4), p. 69; Karl MÖSENEDER, Antonio Bellucci (1654-1715), Herkules als Tugendheld und Belohnung des Wahrheitsstrebens durch die Ewigkeit, Barock 1999 (n. 4), p. 334-335, cat. 87. For Bellucci's life and work, see Fabrizio MAGANI, Antonio Bellucci. Catalogo Ragionato, Rimini 1995. For his arrival and work in Vienna, see Francesca Flores D’ARCAIS, L’attività viennese di Antonio Bellucci, Arte Veneta. Rivista di storia dell'arte, 18, 1964, pp. 99-109; and Fabrizio MAGANI, 1692: Antonio Bellucci da Venezia a Vienna. Note sull'esordio veneziano e la prima attività austriaca, Arte Veneta. Rivista di storia dell'arte, 47, 1995, pp. 20-31. Görz probably saw the ceiling painting in person during his stay in Vienna shortly after it was finished and repeated some figures from the Palais Attems in ceiling paintings in Hämmerlhaus in Eisenerz (1711), which were destroyed during the Second World War. For the destroyed ceiling paintings, see Günter BRUCHER, Die Fresken in der Wallfahrtskirche Maria-Freienstein, ein Werk des steirischen Malers Matthias von Görz, Alte und Moderne Kunst, 117, 1971, pp. 2-8.

41 ALTMANN 1994 (n. 15), pp. 25, 54-55; also Marjeta CIGLENEČKI, Oprema gradov na Slovenskem Štajerskem od srede 17. do srede 20. stoletja, Ljubljana 1997 (doctoral dissertation), pp. 28-29. 


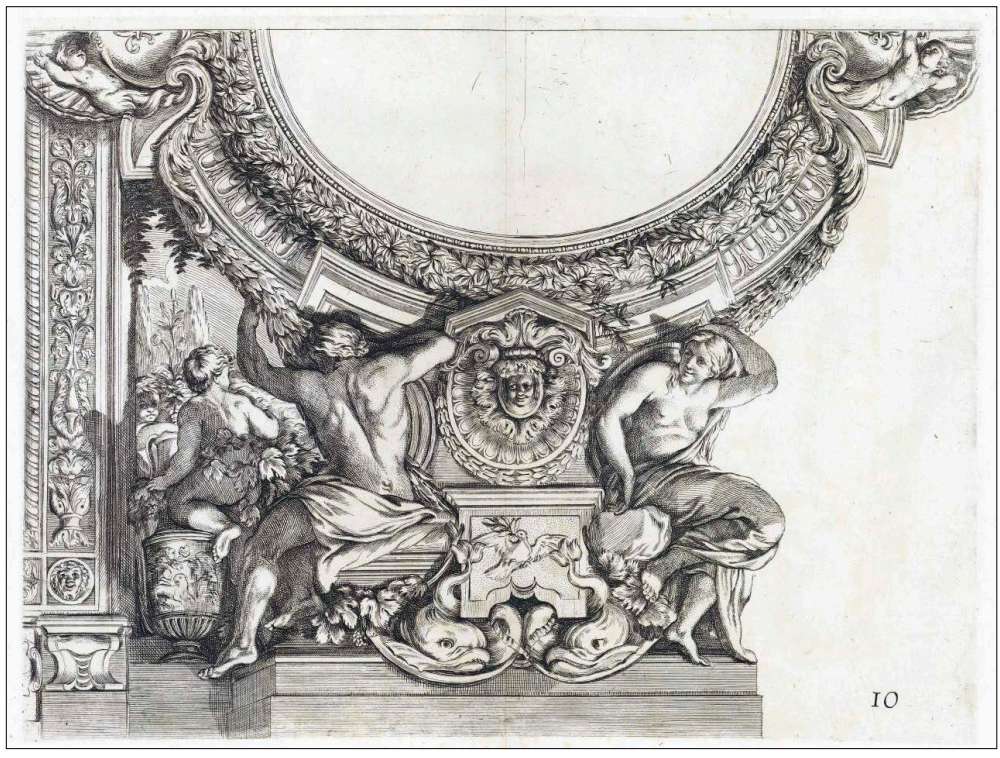

12. Carlo Cesio after Pietro da Cortona: Pair of Ignudi, in: Galeria dipinta nel palazzo del Prencipe Panfilio, Romae, 1661 or later

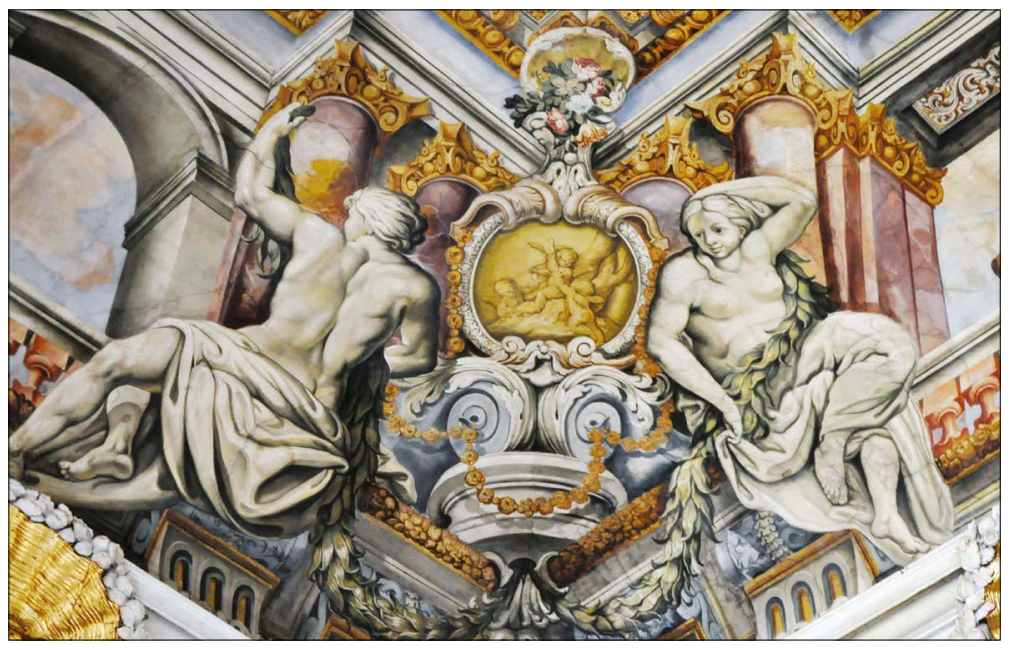

13. Franz Carl Remp: Corner composition (Element of Air), detail of the fresco in the second floor foyer, 1705-1711, Palais Attems, Graz

Remp framed the central figural scene with an illusionistic architectural framework, formed of shortened double columns, and in the corners flanked by pairs of seated Ignudi. ${ }^{42}$ Brucher has already shown that Remp relied while painting the architectural framework on Cortona's ceiling paintings for the Palazzo Pamphilj in Rome (1651-1654); ${ }^{43}$ these frescoes were reproduced in the series Galeria dipinta nel palazzo del Prencipe Panfilio $(1661)^{44}$ by Italian engraver Carlo Cesio (1622-1686). ${ }^{45}$ Cesio's series provided Remp with a compositional template (figs. 10-13). He copied

42 Brucher compared Remp's architectural framework in second-floor foyer with the work of Domenico Piola (1627-1703) in the Palazzo Pantaleo Spinola (1558) in Genoa. See BRUCHER 1973 (n. 4), p. 53.

43 BRUCHER 1973 (n. 4), p. 52.

44 Galeria dipinta nel palazzo del Prencipe Panfilio da Pietro Berrettini da Cortona intagliata da Carlo Cesio, vero originale. In Roma alla Pace alisegna di Parigi si vendono da Giovanni Giacomo De Rossi, 1661 (or later).

45 For Carlo Cesio's life and work, see Antonio VANNUGLI, Cesi[o], Carlo, The Dictionary of Art (ed. Jane Turner), 6, London-New York 1996, p. 362. 
pairs of Cesio's Ignudi, who support the architectural ornaments, while substituting the central ovals with playful groups of putti representing the four elements. Three out of four pairs of Ignudi are almost identical in terms of composition to those depicted on reproductive prints. The position and gestures of some figures were adjusted to fit the composition of the Palais Attems fresco, which can predominantly be seen in the altered positions of their limbs.

Three frescoes in Palais Attems in Graz painted in both the foyers and monumental staircase depict the glorification of the Attems family, as well as the baroque ideals that reach their crowning moment in the patron's apotheoses. They were created in active collaboration between the patron Ignaz Maria Count Attems and his painter Franz Carl Remp. All of them attest to Remp's use of reproductive prints, which served as both a compositional and iconographic source. In some cases, Remp's scenes are almost identical copies of the depictions in reproductive prints, while sometimes they provided only a compositional template or source of motifs, which he combined with other visual sources, creating a whole new iconographic meaning. A difficulty in determining the source of influence is that we often cannot be sure which print the artist used when creating the ceiling paintings, since many reproductive prints circulating in Europe at that time were accessible in several series. We have shown that reproductive prints were one of the key mediators of artistic solutions, and as such were an integral part in the process of creating ceiling paintings. Although there has been no systematic research on the use of reproductive prints in the Remp's oeuvre, we have outlined their role as mediators of ideas in the creation of his frescoes in the Palais Attems which have been the subject of analysis in this article. Further research will surely reveal even more combinations with other visual sources, giving us a more detailed understanding of Remp's work in the Palais Attems. 


\section{Literature}

ALTMANN, Edith, Der Pöllauer Stiftsmaler Matthias von Görz (1670-1731) und seine Zeitgenossen, Graz 1994 (doctoral dissertation).

BARTONI, Laura, Le vie degli artisti. Residenze e botteghe nella Roma barocca dai registri di Sant'Andrea delle Fratte (1650-1699), Roma 2012.

BAUMGÄRTEL, Bettina, Die Tugendheldin als Symbol kirchlicher und staatlicher Macht. Über die Galerie der starken Frauen in Ausstattungsprogrammen und Buchillustrationen, Die Galerie der Starken Frauen/La Galerie des Femmes Fortes. Regentinnen, Amazonen, Salondamen (eds. Bettina Baumgärtel, Silvia Neysters), München-Berlin 1995, pp. 140-223.

BOREA, Evelina, MARIANI, Ginevra, Annibale Carracci e i suoi incisori, Roma 1986.

BRUCHER, Günter, Die Fresken in der Wallfahrtskirche Maria-Freienstein, ein Werk des steirischen Malers Matthias von Görz, Alte und Moderne Kunst, 16, 1971, pp. 2-7.

BRUCHER, Günter, Die barocke Deckenmalerei in der Steiermark. Versuch einer Entwicklungsgeschichte, Graz 1973.

CAMPBELL, Malcolm, Cortona at the Pitti Palace. A Study of the Planetary Rooms and Related Projects, New Jersey 1977.

CIGLENEČKI, Marjeta, Oprema gradov na Slovenskem Štajerskem od srede 17. do srede 20. stoletja, Ljubljana 1997 (doctoral dissertation).

D'ARCAIS, Francesca Flores, L'attività viennese di Antonio Bellucci, Arte Veneta. Rivista di storia dell'arte, 18, 1964, pp. 99-109.

DEMPSEY, Charles, Annibale Carracci. The Farnese Gallery, Rome, New York 1995.

DICKEL, Hans, Deutsche Zeichenbücher des Barock. Eine Studie zur Geschichte der Künstlerausbildung, Hildesheim-Zürich-New York 1987 (Studien zur Kunstgeschichte, 48).

Galeria dipinta nel palazzo del Prencipe Panfilio da Pietro Berrettini da Cortona intagliata da Carlo Cesio, vero originale. In Roma alla Pace alisegna di Parigi si vendono da Giovanni Giacomo De Rossi, 1661 (or later).

Galeriae Farnesianae Icones Romae in aedibus Sereniss. Ducis parmensis ab Annibale Carracio ad Veterum aemuationem posterorumq. admiratioe coloribus expressae cum ipsarum monocromatibus et ornamentis. A Petro Aquila delineatae incisae. Io: Iacobi de Rubeis cura, sumptibus ac typis excusae. Romae ad Templum S. Mariae de Pace cum Privil. Summi Pontificis, 1677.

HENGERER, Mark, Embodiments of Power? Baroque Architecture in the Former Habsburg Residences of Graz and Innsbruck, Embodiments of Power. Building Baroque Cities in Europe (ed. Gary Cohen), New York 2008, pp. 9-42.

Heroicae virtutis imagines, quas eques Petrus Berrettinus Cortonensis pinxit Florentiae in aedibus sereniss. Magni Ducis Hetruriae in tribus cameris, Jovis, Martis, et Veneris. Curâ, \& sumptibus Ioannis Iacobi de Rubeis, cum Priuilegio Summi Pontificis conccesso Anno MDCXCI. die 22. Octobris Romae, Apud Dominicum de Rubeis eiusdem Ioannis Iacobi Haeredem ad Templum S. Mariae de Pace /.../. Superiorum Permissu, Romae 1691.

Imagines Farnesiani cubiculi cum ipsarum monocromatibus et ornamentis Romae in aedibus Sereniss. ducis parmensis. ab Annibale Carraccio aeternitati pictae. A Pietro Aquila delineatae incisae. Io. Jacobus de Rubeis cura, sumptibus, ac typis editae Romae ad Templ. S. Mariae de Pace cum Priv. S. Pont. (1670-1692).

KOHLBACH, Rochus, Steirische Baumeister. Tausendundein Werkmann, Graz 1961.

Die Kunstdenkmäler der Stadt Graz. Die Profanbauten des I. Bezirkes. Altstadt (ed. Wiltraud Resch), Wien 1997 (Österreichische Kunsttopographie, 53).

LANDAU, David, PARSHALL, Peter, The Renaissance Print 1470-1550, New Haven 1994. 
LECHNER, Georg Matthias, Der Barockmaler Franz Carl Remp (1675-1718), Wien 2010 (doctoral dissertation).

LIPOGLAVŠEK, Marjana, Baročno stropno slikarstvo na Slovenskem, Ljubljana 1996.

MAGANI, Fabrizio, Antonio Bellucci. Catalogo Ragionato, Rimini 1995.

MAGANI, Fabrizio, 1692: Antonio Bellucci da Venezia a Vienna. Note sull'esordio veneziano e la prima attività austriaca, Arte Veneta. Rivista di storia dell'arte, 47, 1995, pp. $20-31$.

MARTIN, John Rupert, Immagini della virtù. The Paintings of the Camerino Farnese, The Art Bulletin, 38/2, 1956, pp. 91-112.

MARTIN, Marie-Pauline, Le Cabinet des Beaux Arts de Charles Perrault. Le monument d'un Moderne, La Revue de l'art, 190/4, 2015, pp. 9-18.

MEKE, Katra, Slikarska zbirka Ignaca Marije grofa Attemsa, Zbornik za umetnostno zgodovino, n. s. 50, 2014, pp. 81-127.

MERZ, Jörg Martin, Pietro da Cortona. Der Aufstieg zum führenden Maler im barocken Rom, Tübingen 1991 (Tübinger Studien zur Archäologie und Kunstgeschichte, 8).

MÖSENEDER, Karl, Deckenmalerei, Barock (ed. Hellmut Lorenz), München-London-New York 1999 (Geschichte der bildenden Kunst in Österreich, 4), pp. 303-380.

MÖSENEDER, Karl, Antonio Bellucci (1654-1715), Herkules als Tugendheld und Belohnung des Wahrheitsstrebens durch die Ewigkeit, Barock (ed. Hellmut Lorenz), München-London-New York 1999 (Geschichte der bildenden Kunst in Österreich, 4), pp. 334-335, cat. 87.

MÖSENEDER, Karl, Franz Karl Remp (1674-1718), Merkur und Abudantia sichern den Reichtum des Hauses Attems, Barock (ed. Hellmut Lorenz), München-London-New York 1999 (Geschichte der bildenden Kunst in Österreich, 4), p. 336, cat. 89.

MOSETTIG, Sigrid, Das Stadtpalais der Grafen Attems zu Graz, Sackstrasse 17. Zur Bau- und Ausstattungsgeschichte, Graz 2007 (master thesis).

MUROVEC, Barbara, Grafični listi po Simonu Vouetu in Charlesu Le Brunu kot predloge za baročne stropne poslikave na Kranjskem in Štajerskem, Acta historiae artis Slovenica, 1, 1996, pp. 7-33.

MUROVEC, Barbara, Grafični cikli Ovidovih Metamorfoz in njihov vpliv na baročno slikarstvo na Slovenskem, Ljubljana 1998 (master thesis).

MUROVEC, Barbara, Evropski likovni viri za baročno stropno slikarstvo v Sloveniji, Ljubljana 2000 (doctoral dissertation).

MUROVEC, Barbara, Wagingerjeva alegorija petih čutov v gradu Brežice, Vita artis perennis. Ob osemdesetletnici akademika Emilijana Cevca, Ljubljana 2000, pp. 403-408.

MUROVEC, Barbara, Likovni viri za baročno stropno slikarstvo v Sloveniji, Zbornik za umetnostno zgodovino, n. s. 39, 2003, pp. 92-145.

MUROVEC, Barbara, Lepe umetnosti pod Attemsovim patronatom, Imago Musicae. Glasba na baročnih poslikavah brežiškega gradu (eds. Metoda Kokole, Barbara Murovec), Ljubljana 2016, pp. 12-16.

MUROVEC, Barbara, Historizirana podoba naročnika. Attemsova družinska portreta in Rembov avtoportret iz brežiškega gradu, Acta historiae artis Slovenica, 23/1, 2018, pp. 113-131.

NUSSDORFER, Jolanda Rebecca, Zur Baugeschichte und Ausstattung der Attems-Schlösser: WindischFeistritz (Slovenska Bistrica), Rann (Brežice), Stattenberg (Štatenberg) und Dornau (Dornava) in der ehemaligen Untersteiermark, Graz 1994 (master thesis).

PETRUCCI, Alfredo, Pietro Aquila, Dizionario biografico degli Italiani, 3, Rome 1961, pp. 656-657.

POLLEROSS, Friedrich, Auftraggeber und Funktionen barocker Kunst in Österreich, Barock (ed. Hellmut Lorenz), München-London-New York 1999 (Geschichte der bildenden Kunst in Österreich, 4), pp. 17-50.

RESCH, Wiltraud, Grazer Barockpalais - Ihre Stellung im überregionalen Kontext, Barock. Regional international (eds. Götz Pochat, Brigitte Wagner), Graz 1993 (= Kunsthistorisches Jahrbuch Graz, 25), pp. 305-316. 
SCHIFFER-EKHART, Armgard, Das Stadtpalais der Grafen Attems zu Graz, Graz 1993.

VANNUGLI, Antonio, Cesi[o], Carlo, The Dictionary of Art (ed. Jane Turner), 6, London-New York 1996, p. 362.

WEIGL, Igor, Prenova gradu Podčetrtek v letih 1715-1723, Kronika. Časopis za slovensko krajevno zgodovino, 47/1-2, 1999, pp. 31-42.

WEIGL, Igor, „Die Einheimischen bewundern die Gemälde“. Graf Ignaz Maria von AttemsHeligenkreuz als Auftraggeber und Sammler, Kunsthistoriker, 18/19, 2001/2002, pp. 50-55.

ZADRAVEC, Dejan, Postavitev in postavljavec materialnih in rodbinskih temeljev plemiške družine Attems na Štajerskem, Zbornik občine Slovenska Bistrica. 3: Svet med Pohorjem in Bočem (ur. Stanislav Gradišnik), Slovenska Bistrica 2009, pp. 99-114.

ZORACH, Rebecca, RODINI, Elizabeth, On Imitation and Invention. An Introduction to the Reproductive Print, Paper Museums. The Reproductive Print in Europe, 1500-1800 (eds. Rebecca Zorach, Elizabeth Rodini), Chicago 2005, pp. 1-31.

ŽVORC, Maja, Herculean Allegory at the Čakovec Old Castle: Commissioner and Context, Radovi Instituta za povijest umjetnosti, 41, 2017, pp. 83-96.

\section{Photographic credits}

1, 4, 6, 8, 10, 12: Wikipedia Commons.

2-3, 5, 7, 9, 11, 13: Karin Požin. 


\title{
Rembove stropne poslikave v graški palači Attems. Od grafičnih predlog do fresk
}

\author{
Povzetek
}

Prispevek obravnava vpliv grafičnih predlog na nastanek treh stropnih poslikav v graški palači Attems, ki jih je za pomembnega štajerskega naročnika Ignaca Marijo grofa Attemsa (1652-1732) naslikal Frančišek Karel Remb (1674-1718).

Izhodišče raziskovanja je dejstvo, da so v 17. in 18. stoletju grafične predloge pomembno zaznamovale nastanek poslikav, ki so krasile plemiška bivališča. Ob vseh neposrednih stikih z umetnostnimi spomeniki, ki so jih imeli slikarji in naročniki, so bili prav posamezni grafični listi ključni posredniki tako likovnih idej in vzorov kakor tudi kompozicijskih in ikonografskih virov.

Tri osrednje freske v graški palači Attems, ki jih je Remb naslikal med letoma 1705 in 1711, so tako kot druge štajerske umetnine nastale po vzoru pomembnih stropnih poslikav. S pomočjo alegoričnomitoloških vsebin je slikar upodobil poveličevanje moči in darežljivosti rodbine Attems, ki doseže vrh v treh naročnikovih apoteozah, naslikanih $\mathrm{v}$ obeh preddverjih in na reprezentančnem stopnišču. Pri snovanju fresk je Remb poleg drugih virov uporabljal tudi grafične predloge, na podlagi katerih je mogoče na novo identificirati nekatere prizore s fresk $\mathrm{v}$ graški palači.

Rembov neposredni naslon nanje je viden na freski v preddverju prvega nadstropja, kjer je upodobil apoteozo ostarelega Ignaca Marije grofa Attemsa, ki prejema odlikovanja. Osrednji figuralni prizor je pospremil s štirimi manjšimi, ki aludirajo na moralne vrline plemičev. Trije od štirih prizorov - Scipionova vzdržnost, Sisigambida pred Aleksandrom Velikim in Apolon - so v celoti posneti po grafičnih predlogah iz serije Heroicae Virtutis Imagines (1691), nastale po stropnih poslikavah Pietra da Cortone (1596-1669) v Planetarnih sobah (1641-1665) palače Pitti v Firencah. Remb je pri prenosu figuralnih prizorov na graško poslikavo $\mathrm{v}$ celoti ohranil njihovo kompozicijsko zasnovo in ikonografski pomen.

Tudi na reprezentančnem stopnišču, kjer sta upodobljena Merkur in Abundantia, ki zagotavljata blagostanje hiše Attems, je Remb uporabil grafično predlogo. V dveh manjših kartušah, naslikanih na dveh od štirih robov iluzionističnega arhitekturnega okvirja, je upodobil ženski figuri, pri katerih se je verjetno navezal na grafično predlogo, nastalo po delih Annibala Carraccija (1560-1609) za Camerino Farnese (1595-1597) v Palazzo Farnese v Rimu. Remb je pri vključitvi v graško poslikavo ohranil prvotno kompozicijo ženskih teles, dodal pa je putte in ju umestil v stilizirano pokrajino. Prilagodil je tudi njun ikonografski pomen - Inteligenco je spremenil v Diano z lokom, Čistost pa v Venero s putti.

Naslon na grafične predloge je viden tudi pri ignudih in atlantih, ki pri freskah $\mathrm{v}$ obeh preddverjih bogatijo videz iluzionističnih arhitekturnih okvirjev. V obeh omenjenih primerih Remb ni v celoti prekopiral upodobitev z grafičnih predlog, ki so prav tako nastale po italijanskih stropnih poslikavah, temveč je njihovo kompozicijo prilagodil arhitekturnim danostim prostora graške palače. S tem je pokazal, da je bil z grafičnimi predlogami sposoben ravnati dovolj svobodno, jih prilagoditi naročnikovim željam in v kombinaciji z drugimi viri ustvariti nove umetniške stvaritve, ki sodijo med pomembnejša dela štajerskega baroka. 